DEPARTMENT OF THE INTERIOR

UNITED STATES GEOLOGICAL SURVEY GEORGE OTIS SMITH, DIRECTOR

\title{
SUMMARY OF THE
}

\section{CONTROLLING FACTORS OF ARTESIAN FLOWS}

\author{
BY \\ MYRON L. FULLER
}

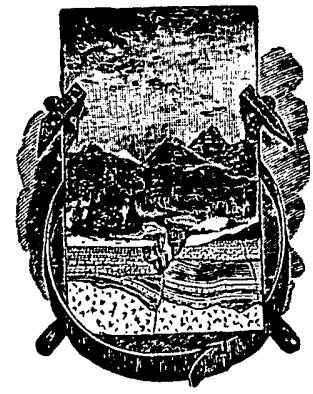

WASHINGTON

GOVERNMENT PRINTING OFWICE 1908 



\section{CONTENTS.}

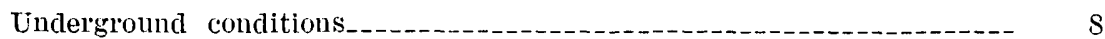

Underground reservoirs _._._._.

Types -

Original forms

Original pores _..... 9

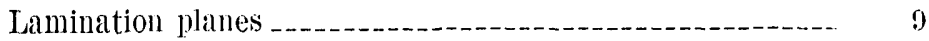

Bedding planes _.

Vesicles__-__-_._. 10

Secondary forms

Secondary pores _..._-_._._. 11

Solution openings _._._._. 11.

Mechanically formed reserroirs_......

Fracture openings _._.

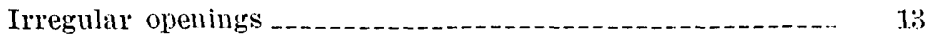

Joints -..-

Vein contacts_._.

Igneous contacts-_-

Faults _.

Shearing planes____. 15

Cleavage planes_..._._. 15

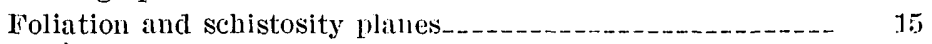

Sources of underground water-_-__._.

Waters from the atmosphere__._._.

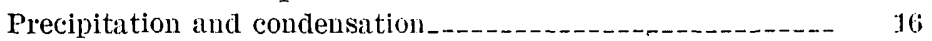

Waters from lakes and streams._. 1.7

Waters from the ocean

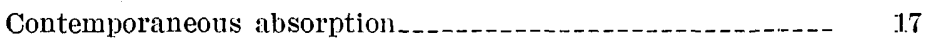

Originally included sea water._........ 18

Waters from the rocks of the crust_..._.

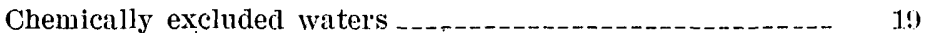

Physically excluded waters _._.

Waters from the centrosphere

Confining agents_..... 20

Bedded rocks_.... 21.

Upper confining agents_-_-_._. 21 .

Impervious bed 21.

Stratification planes.-_- 21.

Friction

Mineral crusts_-_._-_._- 23

Frost zones _._.

Confinèd air and gas._..........

Fresh water-_._.

Sea watter-_..._. 
Underground conditions-Continued.

Confining agents-Continued.

Bedded rocks-Continued.

Lower confining agents.

Cementation

Heat

Jointed rocks

Upper confining agents__-_.

Impervious wall_._._._._._._. 26

Impervious covering on surface

Frost fillings_._.

Vein fillings _._.

Weathering products_..._._._.

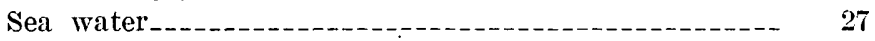

Converging walls _......._. 27

Interruptions of joints _....... 27

Lower confining agents_._._._. 27

Nature of artesian circulation _-_._- 27

Primary factor ...._._._._. 28

Gravity _._.

Modifying factors

Factors mainly affecting pressure

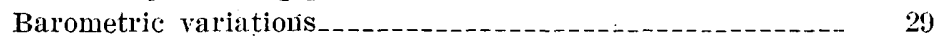

Temperature variations__.

Density of waters._._._- 30

Variations due to temperature_................ 30

Variations due tordissolved salts___._._._._._._._._. 30

Variations due to suspended solids________..... 30

Height of adjacent water levels _-_ 31

Water table

Neighboring water bodies, etc_-_. 31

liock pressure _-_-_- 33

Factors mainly affecting wạter movements_______-__-__- 33

Requisites of artesian flows

Objections to common requisites. 34

Pervious stratum _._. 34

Impervious bed below

Impervious bed above__-___. 35

Inclination of beds

Outcrop of porous stratum

Adequate rainfall__._. 36

Points of escape _._. 36

Essentials of artesian flows _._. 36

Modifying factors s $_{-}$

Typical artesian systems _._. 37

Artesian basin

Artesian slope_.__

Unconfined horizontal beds_-_._- 39

Bedding planes _-_- 39

Solution passages _..._- 39

Frost or mineral crusts_._._._. 40

Vesicular trap 
Requisites of artesian flows-Continued.

Typical artesian systems-Continued.

Weathered rocks beneath clays_..._........ 40

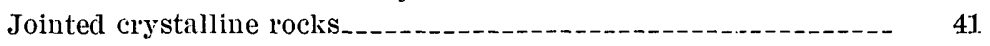

Basins fed by joints_-_-_._-_._- 41

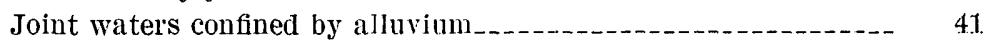

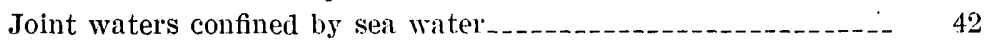

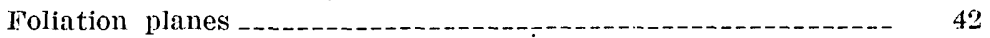

Fault and contact planes._-_. 42

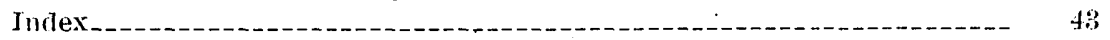





\title{
SUMMARY OF THE CONTROLLING FACTORS OF ARTESIAN FLOWS.
}

\author{
By Mrron L. Fuller.
}

\section{INTRODUCTION.}

Every text-book on geology and every treatise on hydraulics or hydrology discusses the occurrence of artesian waters. Unfortunately, however, only the more simple conditions are usually considered. The principle expressed by the widely prevalent maxim, " water seeks its own level," is readily grasped by every one, but it does not explain all of the features of artesian flows. That nature does not always do its work in the simplest way is recognized in all sciences, in none more generally recognized than in geology or hydrology. The ideal conditions shown in the text-books and treatises are often absent; while, on the other hand, flows occur under a great variety of conditions not commonly recognized and rarely described. The ever-present basin of popular discussions does not even predominate among the many types of artesian systems encountered in the field, and even the sloping bed is not essential. On the other hand, fissures and solution passages play very important párts, even in stratified rocks.

For these reasons and because of the present activity in artesian investigations, but more especially because of the notable change in the use of the term "artesian" since the publication in 1885 of the admirable paper of Prof. T. C. Chamberlin on the "Requisite and qualifying conditions of artesian wells," a it has seemed desirable to point out certain needed modifications to the postulated requisites of flow. No attempt at exhaustive treatment is made, the aim being simply to call attention to a few of the commonly neglected elements of the problem.

In view of the number of different senses in which the term artesian has been used in the past it will not be out of place to state that in the present paper the term is applied in the sense adopted by the United States Geological Survey after consultation with 
leading geologists of the country, namely, to designate the hydrostatic principle by which confined waters tend to rise in virtue of the pressure of the overlying water column, whether or not this pressure is sufficient to lift the water to the surface and produce a flow. ${ }^{*}$

\section{UNDERGROUND CONDITIONS.}

Preliminary to the discussion of the essential factors of artesian flow, a résumé of the geologic conditions affecting artesian waters is desirable. The following paragraphs present some of the factors bearing on the occurrence and movements of such waters.

\section{UNDERGROUND RESERVOIRS.}

TYPES.

By "underground reservoir" is meant the opening or system of openings in which underground water is contained. It is needless to say that, except an occasional cavern of very limited extent, such reservoirs bear no relation to open basins of the surface type, but are most of them rock strata or masses in which the only openings are spaces between the grains or along lines of solution or of jointing, cleavage, bedding, or other structure planes or fissures. Among the various types of reservoirs the following are the most important water producers:

\section{Types of underground resernoirs.}

I. Original forms.
A. Original pores.
B. Lamination planes.
C. Bedding planes.
D. Vesicles (in igneous rocks only).

II. Secondary forms.

- A. Secondary pores.

1. Pores resulting from leaching and solution.

2. Pores resulting frou recrystallization.

B. Solution openings.

1. Isolated cavities.

2. Tubular channels.

3. Sheet openings.

C. Mechanically eroded reserroirs.

1. Tubular channels.

2. Pocket openings.

3. Sheet openings.

D. Fracture openings.

1. Irregular openings.

a. Desiccation cracks.

b. Contraction fissures.

a Fuller, M. L., Significance of the term "artesian :" Water-Sup. and Irr. Paper No. 160, U. S. Geol. Survey, 1906, pp. 9-15. 
II. Secondary forms-Continued.

D. Fracture openings-Continued.

1. Irregular openings-Continued.

c. Torsion fractures.

d. Shearing breaks.

e. Vibration fractures.

f. Explosion ruptures.

2. Joints.
a. Vertical joints.
b. Horizontal joints.
c. Parallel joints.
d. Intersecting joints.
e. Joint breccias.

3. Faults.
a. Single tault planes.
b. Parallel fault planes.
c. Irregular faults.
d. Intersecting faults.
e. Fault breccias.

4. Vein contacts.

5. Igneous contacts.

6. Shearing planes.

E. Cleavage planes.

F. Foliation and schistosity planes.

Most of the forms enumerated are not limited to any particular class of rock, but may be found in the stratified, metamorphic, and igneous types. The vesicles of igneous rocks, however, have no exact counterpart in stratified rocks, although the pores containing included water of sedimentation approach them in nature. Solution channels are likewise usually, although not necessarily, found only in sedimentary rocks; foliation and schistosity are mainly features of igneous or metamorphic rocks, while lamination, as the term is here used, is a feature of stratified rocks.

\section{ORIGINAL FORMS.}

Original pores.-The original pores include both the pores of the primary rocks and the unfilled spaces between the fragments or grains of the fragmental and other secondary rocks, including till, sand, and gravel; sandstone and conglomerate; oolite, shell limestones, chalk, etc. The minute pores in clays, as well as the intercrystal spaces resulting from the contraction and adjustment incident to the cooling of igneous rocks, belong in this class, although these are usually far less important than the macroscopic pores of the coarser sedimentary rocks. The original pores rank first in water-bearing capacity, characterizing all of the best-known types of water beds.

Lamination planes.-Lamination planes, or the crowded partings which separate certain of the finer stratified rocks into numberless thin sheets or laminæ parallel to the bedding, are of considerable im- 
portance. Many shales, especially. where the partings have been somewhat opened by the weather near the surface, carry larg: amounts of water in such planes. The general exudation of water from laminated beds, such as often occurs throughout a considerable vertical range where the layers are exposed in cliffs or in the artificial faces of quarries, is familiar to everyone.

Bedding planes.-Bedding planes, or the partings between individual layers or beds of the same or different classes of rock, often carry large amounts of water. This is in part due to the fact that the adhesion along such planes is less than that in a mass of homogeneous material, a condition which results largely from the imperfect contact due to variations of material, changes in texture, variations in arrangement, etc., which have resulted from changes or halts in deposition. This lack of adhesion makes the bedding planes more readily available for the passage of water than the body of the rock. Difference in permeability of the overlying and underlying layers is also a leading factor in the concentration of water along the bedding planes, making the latter, next to the original pores, the most important water containers. This is especially true where the planes have been somewhat widened by subsequent solution admitting the free passage of water, as shown in $\mathrm{Pl}$. I, $A$.

Vesicles.-Vesicles, or cavities resulting from the expansion of steam in cooling lavas, form a distinct although not a common type of reservoir. Usually the vesicles are very imperfectly connected, but in some of the Newark lavas, such as have been described by B. K. Emerson and others, the vesicular portions of the trap seem to form a definite water horizon. The same is doubtless true of many other scoriaceous lavas, both those occurring on the surface and those buried beneath subsequent deposits. The possibility of a general water movement through such materials is shown by their secondary mineralization, seen in both mines and surface exposures. The almost universal mineralization of the upper vesicular portions of the copper-bearing traps-the amgydaloids - of. Keeweenaw Point, Lake Superior, is a particularly good illustration of deep-seated movements in such zones.

In the same class with the vesicles, though of different origin, may be placed the cavities due to contraction of igneous magmas on cooling, especially magmas of the acid type. Original, crystal-lined openings up to 3 feet in diameter have been noted by the writer in the pegmatites of New Hampshire, and minute cavities exist in many other rocks. While rarely important as containers of water, they are, nevertheless, of sufficiently common occurrence to necessitate their inclusion with the other possible reservoirs. 


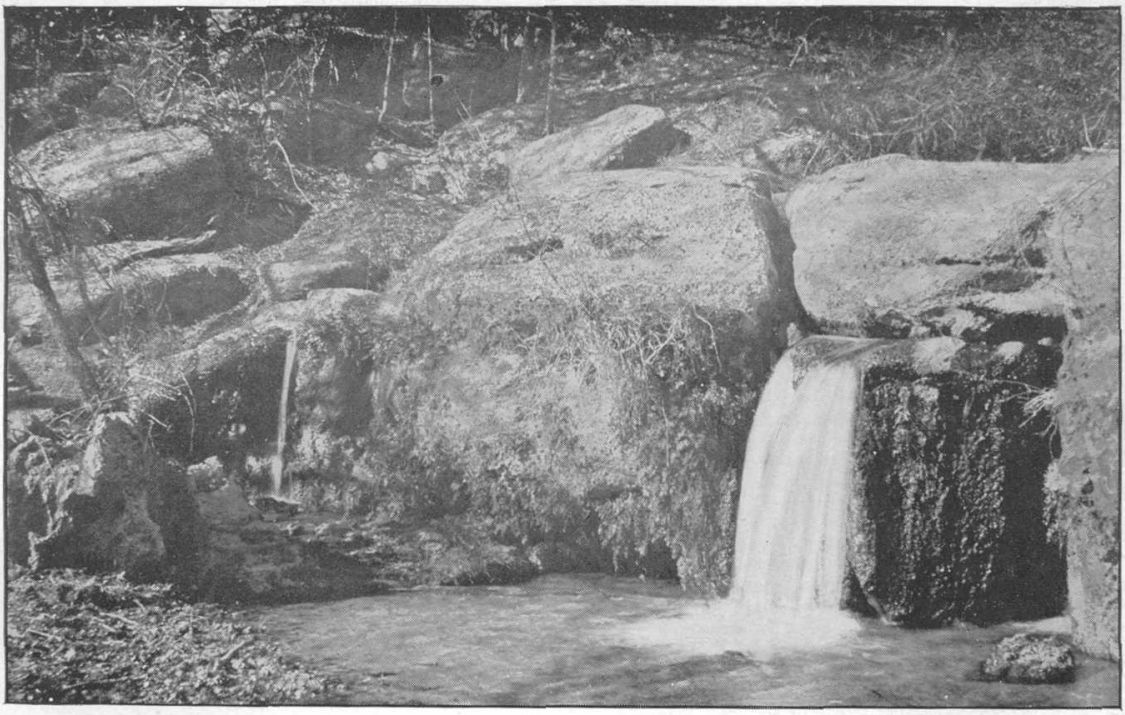

A. THE BEDDING PLANE; SPRING EMERGING FROM BEDDING PLANE IN LIMESTONE.

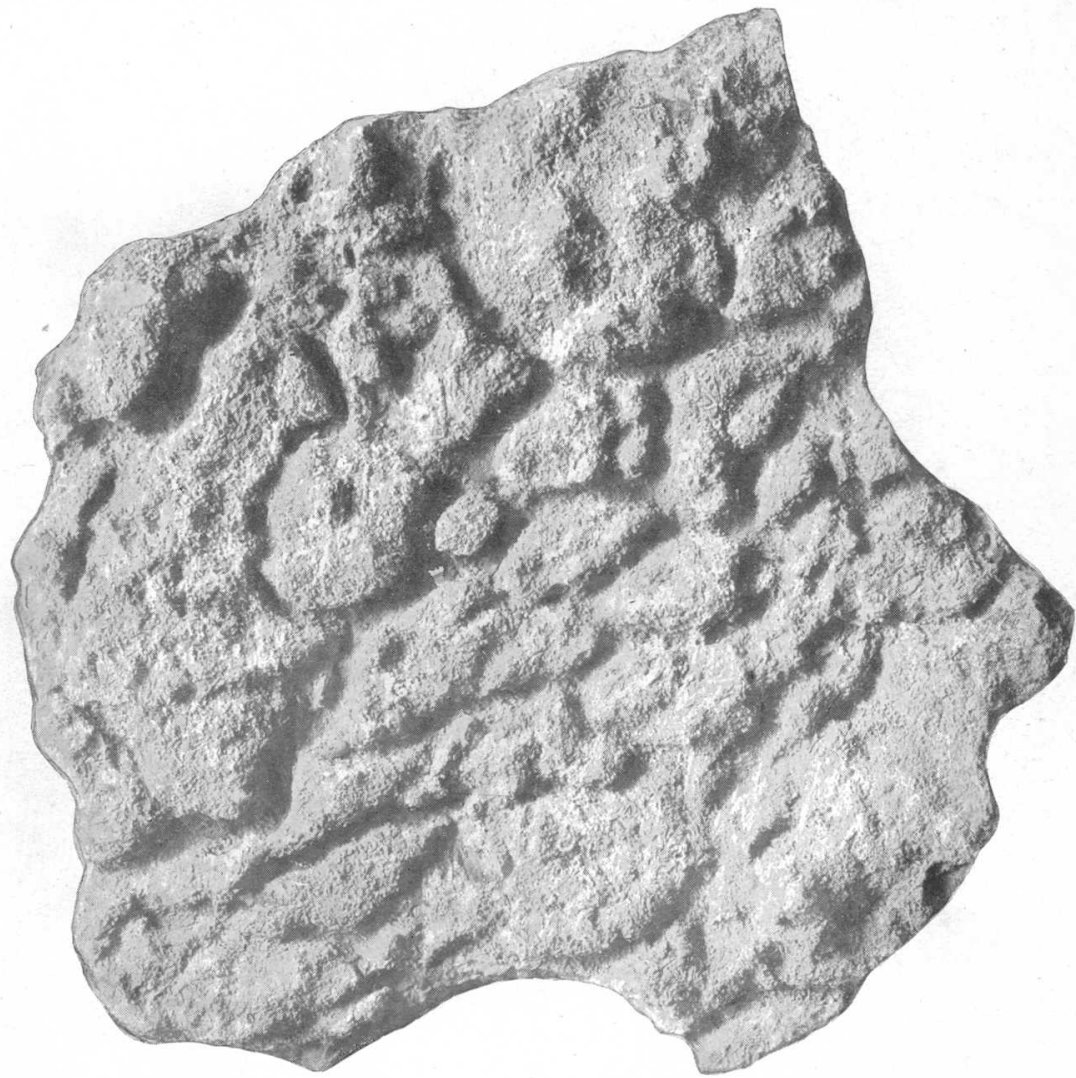

2. RAMIFYING CHANNELS ALONG BEDDING PLANE IN LIMESTONE. 
SECONDARY FORMS.

Secondary pores.-By secondary pores are meant those minute spaces-too small to be designated as openings. or cavities-which have resulted from the processes of weathering, solution, recrystallization, etc. Many of these are of much importance. The dolomitized portion of the Trenton limestone in parts of Ohio and Indiana, for instance, is sufficiently porous to carry considerable volumes of water; the original cement has been removed from calcareous sandstones in many areas, leaving them open and porous; soluble minerals, such as pyrite and calcite, are here and there leached from their relatively insoluble matrix, leaving notable open spaces; and the grains of crystalline rocks become so loosened by weathering for a depth of many feet that the material absorbs water almost like a sponge. It is doubtless through the formation of secondary pores that circulation is established along many of the lamination and bedding planes, leading eventually to the formation of open solution passages.

Solution openings.-These are among the most important of the secondary reservoirs and, as their name implies, are formed by the solvent action of percolating waters. They may be divided for convenience into. (1) isolated irregular or roughly spherical reservoirs and (2) elongated passages or channels of tubular or sheet form.

The first of these types, at least where not connected with other passages, seems to be of rare occurrence. Many geodes, however, showing horizontally banded fillings, occur in the body of limestones without connection with recognizable openings through which the mineralized solutions could have entered, the spaces apparently being first dissolved and then gradually filled by water entering through the pores of the body of the rock. It is not impossible that some of the ore pockets in certain limestones may be of this origin, although by far the greater part of these seem to be direct replacements.

Of the elongated passages or channels, the ordinary caves are the best examples (Pl. II, $B$ ). Some of them are of great length, a single passage in the Mammoth Cave of Kentucky being over 8 miles long. Many such passages are 20 feet high; a few are as high as 75 feet; and some are as much as 50 to 150 feet wide. Some of the chambers which have been penetrated by mining shafts have shown hardly $\dot{a}$ trace of the openings through which the water entered or passed out, the openings simulating on a large scale the geode cavities described. The great vertical wells of the Mammoth and other caves; having diameters of 10 feet or more and depths of more than 200 feet, and the similar " natural wells" of Florida and elsewhere also belong to this class. 
Many of the channels of this type have resulted from the enlargement of joints, the action being especially marked near the intersection of two or more planes, the great irregularity of some of the openings being accounted for by the complexity of the joint or fracture systems. This appears to be the case in the Joplin zinc district. Elsewhere, however, many of the largest passages follow bedding planes without reference to jointing, apparently having developed from one of the many meandering and branching passages that characterize such planes at many points. A view showing a network of small channels on one of these bedding planes is reproduced as Pl. I, $B$. The small channels are gradually enlarged and tend to coalesce and form a single large channel which, by continued solution, is gradually widened until a cave results. A few small tubular channels that pass diagonally through the rock without apparent connection with joints or bedding planes have been noted. The determining causes of such passages are not known, but it seems certain they represent simply the enlargements of some preexisting line of easy water movement.

The sheet form of solution passage is the first stage in the enlargement of joints, faults, or other planes. The secondary pores first formed eventually unite into an exceedingly narrow sheet-like opening. In crystalline and other insoluble rocks these may persist indefinitely, but in limestones differential solution soon develops the characteristic irregular cavities.

Mechanically formed reservoirs.-These include (1) irregular, but usually more or less tubular passages, many of which are followed by waters, in clay, till, and similar materials, and (2) certain of the water-bearing gravel pockets. The former may frequently be examined in detail where springs emerge from bluffs. In general they are from 1 to 4 inches in diameter, although larger ones doubtless occur, and are probably of considerable length. Their manner of formation is very similar to that of the limestone passages, except that the action is mechanical instead of chemical. The water finds its way along some bedding, joint, or other plane, gradually picking up and carrying away, particle by particle, the fine material with which it comes in contact until an open passage finally results.

Allied to these passages in manner of formation are the gravel pockets in till. Flowing wells from tills have been known to bring up cartload after cartload of clay and fine sand, until the original mixture of clay and pebbles about the well has given place to a loose and open gravel. Similar pockets appear to have been formed in many places by natural circulation, where springs have broken through till deposits, and extensive layers of gravel are believed to have been produced where general movements have occurred along lamination partings within the till. 


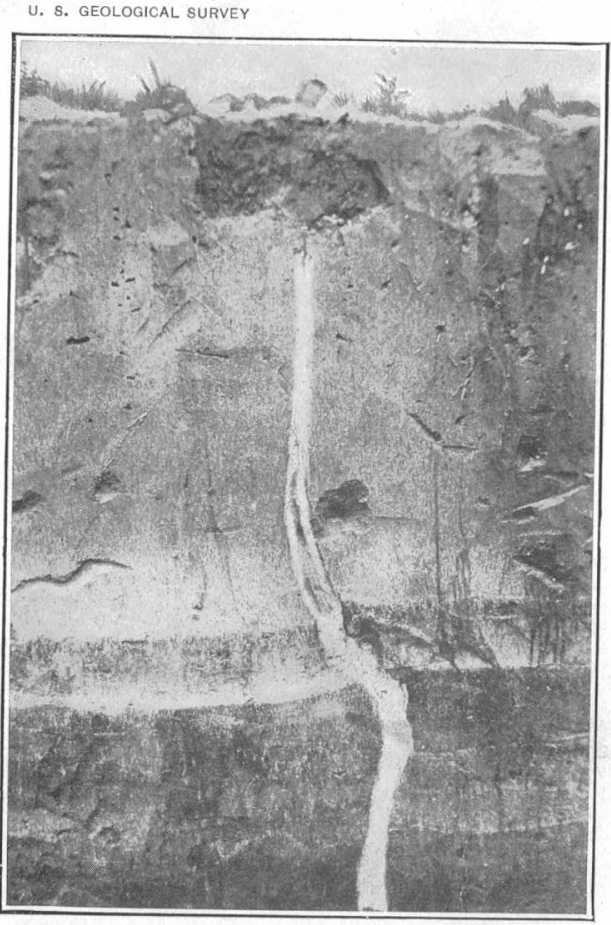

A. EARTHQUAKE CRACK FILLED WITH SAND DIKE, BETWEEN WALLS OF CLAY.

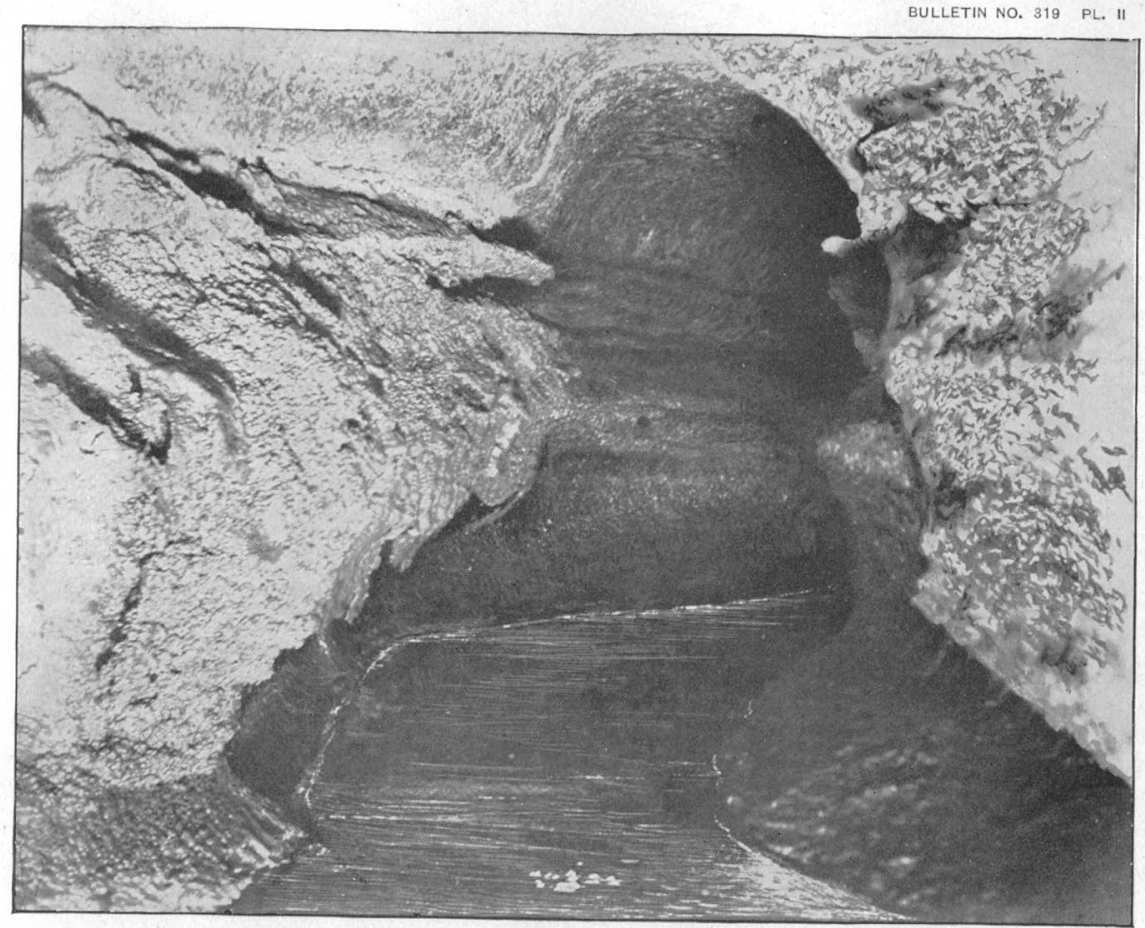

B. UNDERGROUND SOLUTION CHANNEL.

ARTESIAN RESERVOIRS. 


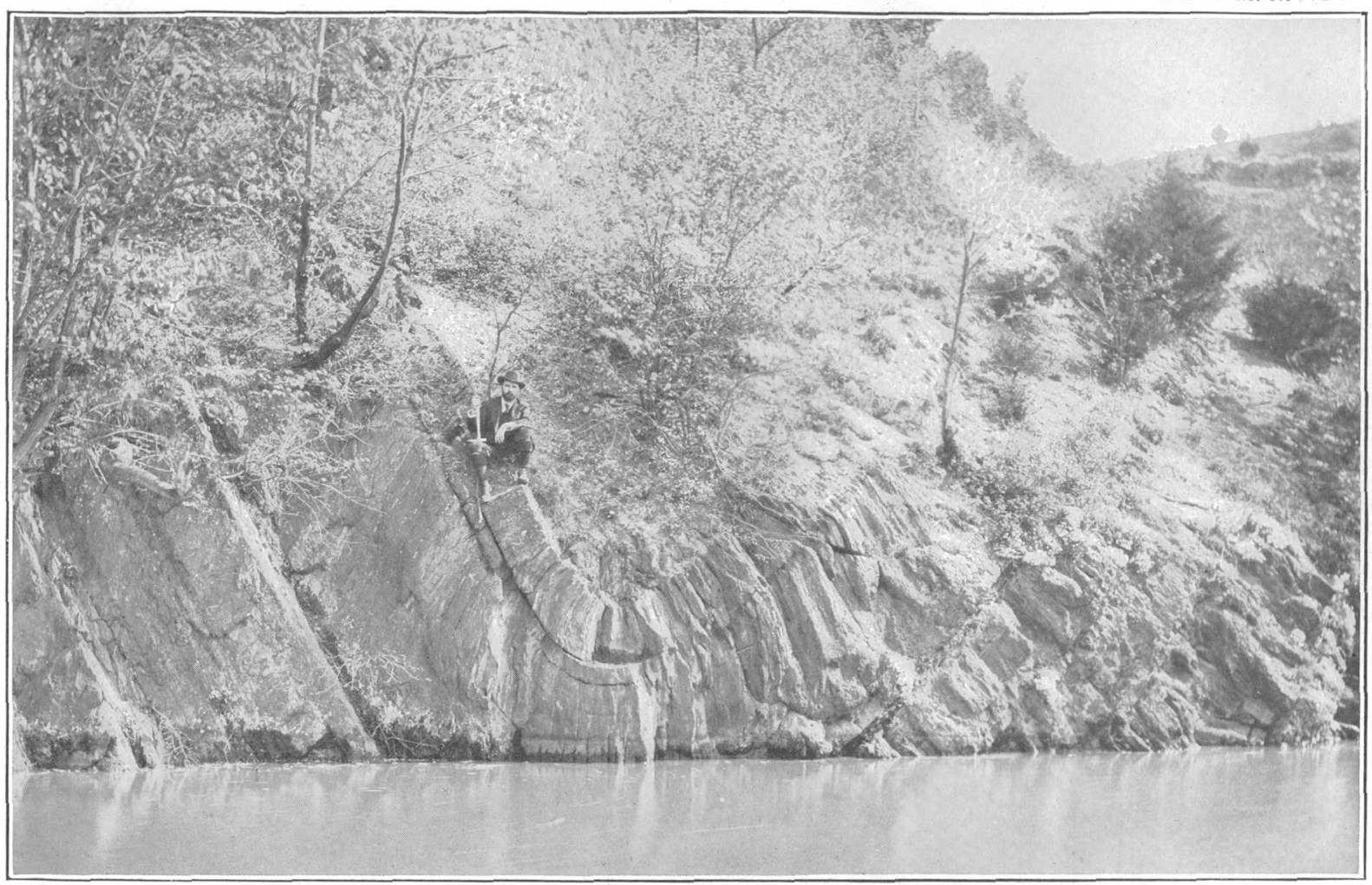

ARTESIAN RESERVOIRS; TORSION CRACKS DUE TO FOLDING. 
Fracture openings.-Under this head are included a number of openings of varying character, due to a wide range of causes. Joints and irregular fissures are the most common types and may be classedaccording to the presence or absence of movement of the walls-as simple or fault openings.

The immediate cause of all such openings is probably local tension, although compression is frequently the indirect cause. Fractures resulting from the contraction of the rocks accompanying cooling; dehydration, etc., are caused solely by tension, but in expansion or dilation due to hydration, etc., the local tension giving rise to the fractures is simply an incidental result of the pressure resulting from the expansion. Similarly, the so-called compression fissures or cracks - formed in a rock cube subjected to heavy pressure, while resulting from the compression of the block as a whole, are in themselves due rather to local tension developed as a result of readjustments under the influence of the pressure. Again, in the case of rock folds, although pressure produces the arching, it is the tension developed by the bending that actually produces the fractures (Pl. III). For convenience of discussion fracture openings are here divided into irregular openings, joints, faults, and igneous and vein contacts.

Irregular openings.-In this class are included several types of openings, such as the intersecting cracks formed by the dessication of wet silts, the fractures resulting from the contraction of igneous rocks on cooling, the breaks arising from the distortion of beds in folding, the gashes produced in the adjacent rock mass by the drag incident to faulting or by the movements accompanying expansion by hydration, the cracks caused by earthquake waves in soft materials (Pl. II, $A$ ), and possibly certain profound fractures due to the general cooling of the earth's crust. In the same class should probably be placed the irregular but more or less circular openings connecting with surface "craterlets," formed by the occasional expulsion of gas ${ }^{a}$ arising from the decay of woody matter in unconsolidated formations and by the expulsion of water through the body of the soil (not through the cracks) in time of earthquakes. ${ }^{b}$

Openings of the types outlined are of common occurrence and wide distribution, but in the main are of small size. Occasionally, however, even where there has been no faulting, they are, as attested by fissure veins, of considerable width and have afforded passages for immense volumes of water.

Joints.-For the purpose of this discussion the details of the origin of joints need not be considered, and they may be simply defined as

a Shaler, N. S., Conditions and effects of the expulsion of gases from the earth: Proc. Boston Soc. Nat. Hist., vol. 27, 1896, pp. 89-196.

o Dutton, C. E.. The Charleston earthquake of August 31, 1886 : Ninth Ann. Rept. U. S. Geol. Survey, 1889, pp. 203-328. 
smooth fracture planes cutting the rock in various directions, but unaccompanied by any differential movement of the walls. Joints vary in position from vertical to horizontal, but commonly make an angle of $70^{\circ}$ or more with the horizon. The spacing also varies greatly according to the character of the rock and the disturbance to which it has been subjected, but on the whole the spaces between joints are greatest in sandstones and similar rocks and smallest in slates. In the latter rock it is not infrequent to find, on the one hand, zones broken up by parallel joints into thin sheets (PI. IV) and, on the other hand, zones cut up by intersecting joints into minute rhombs, converting the mass into what may be termed joint breccias $(\mathrm{Pl}$. V,$B)$. An investigation of the granites of Connecticut made by Mr. E. E. Ellis ${ }^{a}$ showed that the spacing of the vertical joints at the surface commonly ranged between 3 and 7 feet, while the horizontal joints varied from an average of 1 foot apart in the upper 20 feet of rock to 6 to. 30 feet apart in the succeeding 80 feet $(\mathrm{Pl} . \mathrm{V}, A)$. The width of the openings varied from 2 inches at the surface to a fraction of a millimeter at depths of 25 to 100 feet.

Notwithstanding the narrowness of the joint openings, experience in mining regions and in quarries has shown the existence of connecting systems extending over large areas. At Cripple Creek, for instance, as described by Lindgren and Ransome, ${ }^{b}$ the system of connecting joints extends over an area 3 miles in diameter and is so open that the entire tract might be drained from a single point. The volume of water held, in such a system is enormous and its removal by pumping often entails great expense to the mines. Quarries also frequently have trouble with water, and heavy pumps must sometimes be installed to remove it. . In general the circulation in vertical joints is much greater than in horizontal joints, water being especially abundant where two or more fractures of the former type intersect.

Vein contacts.-Many of the contacts of veins with their wall rocks are characterized by extensive circulation of water, which, like the waters in joints, often interferes seriously with mining and adds greatly to its cost. In general, however, the passages are very small, the water following, at least at first, the almost inappreciable openings along the walls, where, as along many bedding planes, the water finds access because of the imperfect nature of the contact between unlike materials In true veins the original fracture is probably most commonly a joint plane, but deep irregular fissures are not uncommon. In segregation veins the contacts may be regarded as solution surfaces.

\footnotetext{
${ }^{a}$ Ellis, E. E., Occurrence of water in crystalline rocks: Water-Sup. and Irr. Paper No. 160 , U. S. Geol. Survey, 1906, pp. 19-28.

${ }^{b}$ Lindgren, Waldemar, and Ransome, F. L., Report of progress in the geological resurvey of the Cripple Creek district, Colorado: Bull, U. S. Geol. Survey No. 254, 1904, pp. 31-32.
} 


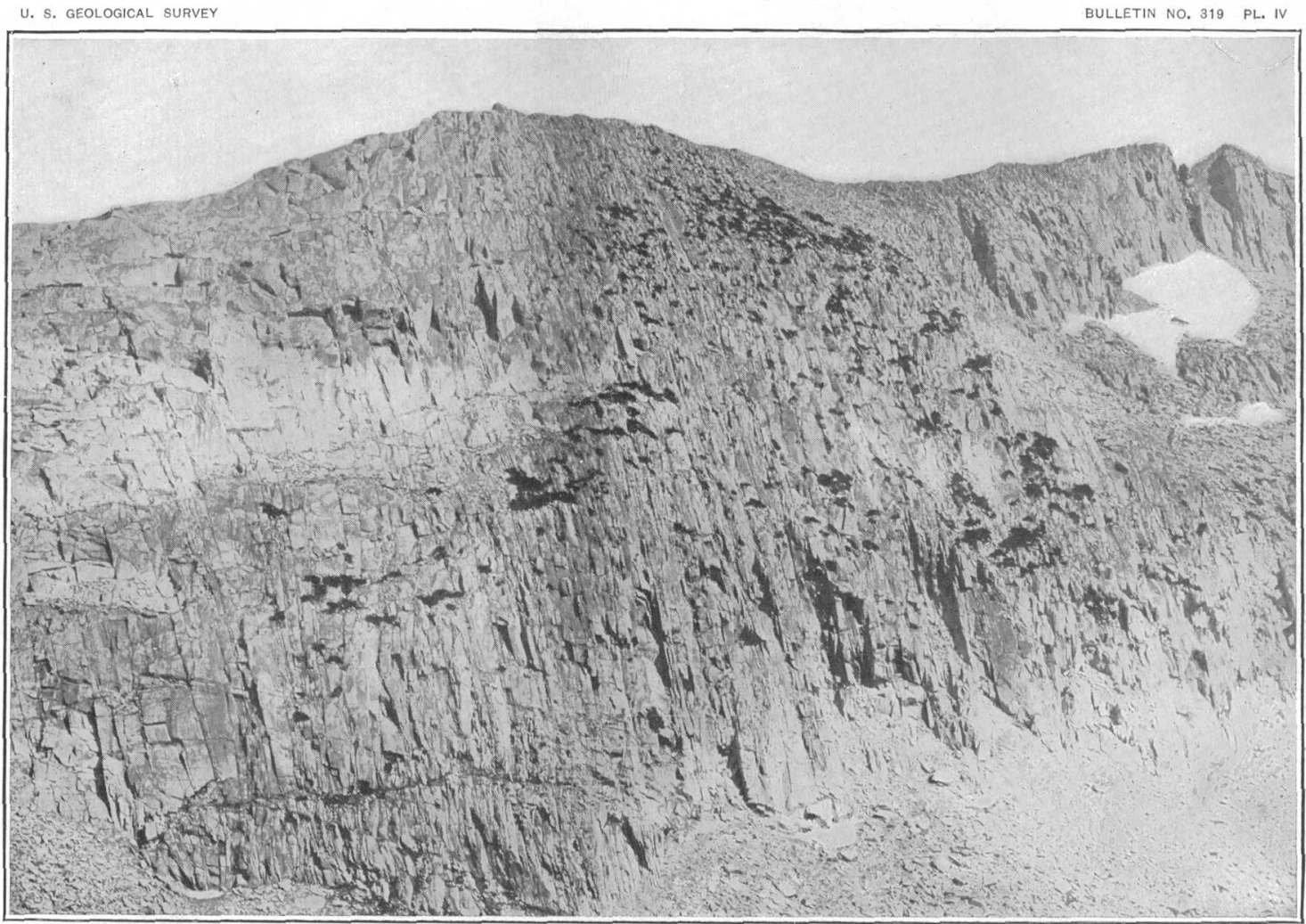

ARTESIAN RESERVOIRS; SHEET JOINTING. 


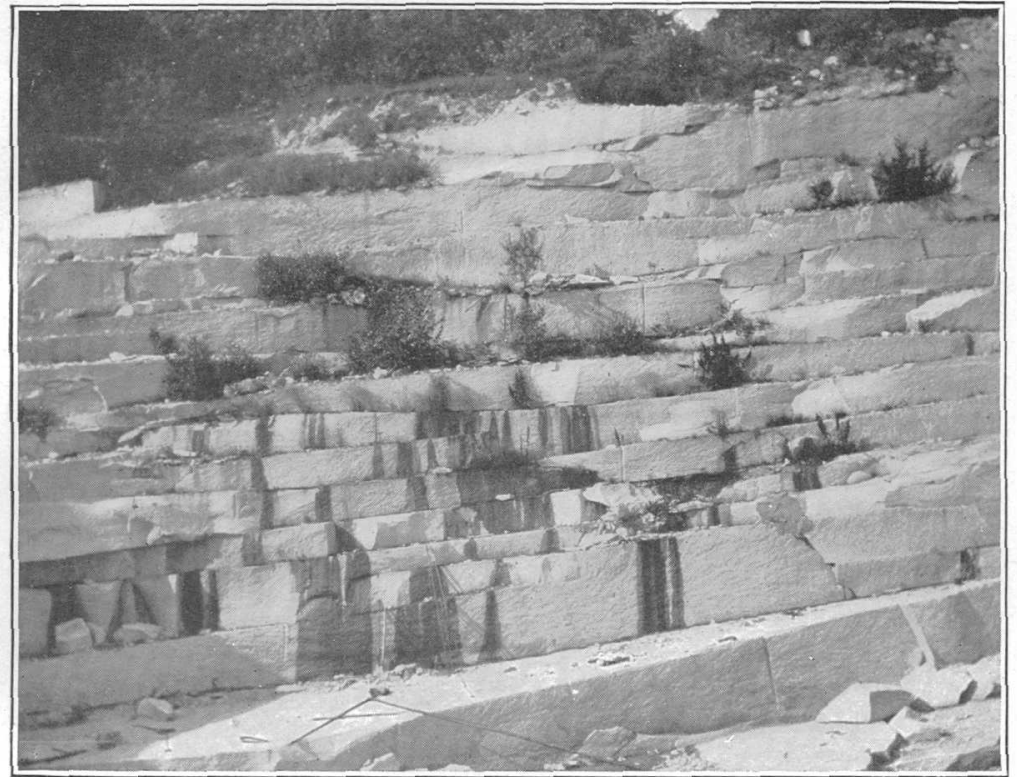

A. HORIZONTAL JOINTS IN GRANITE.

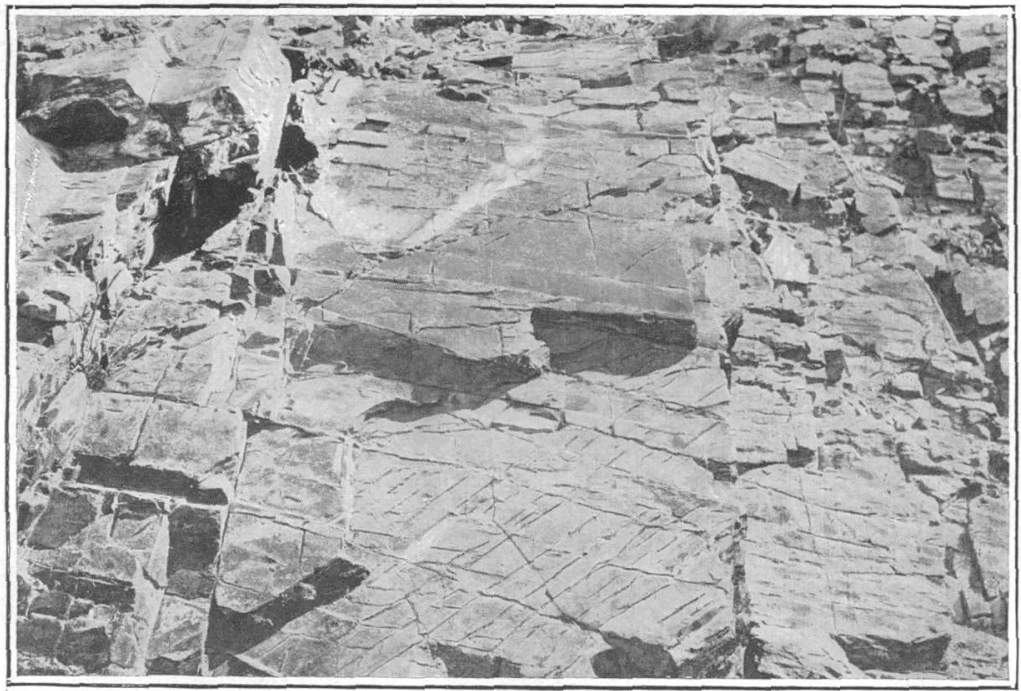

B. JOINT AND FAULT BRECCIA.

ARTESIAN RESERVOIRS. 
Igneous contacts. - What has been said of the vein contacts applies with equal force to the igneous contacts of the dikes or sills intruded into joints, bedding planes, or other preexisting fractures or lines of separation. In some places igneous masses, as certain acid pegmatites, have actually eaten their way into the country rock, and the contacts often have no relation to previous structures. They are, however, less likely to afford favorable conditions for the circulation of water than the contacts of the normal type.

Faults.-Although faults are far less numerous than joints, they are more likely to be associated with extensive circulation systemis than the latter (Pl. VI, A). This, in large measure, is the result of the movement of the walls by which opposing projections are brought opposite one another, leaving intervening openings along which the water freely circulates. Sheeted zones, with large numbers of closely adjacent parallel fault planes, and crushed zones or fault breccias, are also common, and likewise afford exceptionally good water passages and reservoirs (Pl. VI, $B$ ).

Shearing planes.-Shearing is closely allied to faulting, inasmuch as it implies a differential movement of adjacent portions of the rock, but differs from faulting in that it usually comprises no lines of definite fracture, but consists rather of a readjustment of the material along parallel planes throughout the rock. At the start there are no actual openings, but the shearing planes are lines of weakness and are more or less permeable to water, and, when near the surface, rapidly widen into material openings under the influence of the weather, often becoming reservoirs of importance.

Cleavage planes.-These are more or less vertical planes, produced by the action of pressure, etc., on certain compact rocks such as slate. Unlike most joints, they are not ordinarily actual fracture planes, but are simply lines along which the rock tends to split under favorable conditions. It is not probable that they carry much water when at a depth, but near the surface, where they have been somewhat opened by the agencies of weathering, considerable quantities are frequently stored in them (Pl. VII, $B$ ).

Foliation and schistosity planes.-These planes, dependent upon the parallel arrangement of the crystalline components of igneous or metamorphic rocks, are similar in many ways to the shearing and cleavage planes, being potential rather than actual rifts, but under the action of the weather appreciable openings holding considerable quantities of water soon develop. Some weathered schists appear to hold 15 per cent or more of their bulk of water (Pl. VII, $A$ ).

\section{SOURCES OF UNDERGROUND WATER.}

The probable source of underground waters has been widely discussed, and while everyone would doubtless agree that by far the 
greater part is derived from rainfall there is a considerable variation of opinion as to the relative importance of the other sources, especially as to the part played by the sea and aqueous magmatic emanations. The common sources of underground waters are given below:

\section{Sources of underground waters.}

I. Atmosphere.

1. Direct.

a. Frecipitatiou.

b. Condensation.

2. Indirect.

a. Lakes.

b. Streams.

II. Hydrosphere, or ocean.

1. Contemporaneously absorbed waters.

2. Originally included sea water.

III. Lithosphere, or crust. ${ }^{a}$

1. Primary waters.

a. Chemically excluded waters.

2. Secondary waters:

a. Physically excluded water's.

IV. Centrosphere, or interior. ${ }^{a}$

1. Water's directly excludet.

2. Indirectly excluded magmatic waters.

WATERS FROM THE ATMOSPHERE.

Precipitation and condensation.-Water from the atmosphere, aside from the amount entering immediately into chemical combination with surface materials, reaches the surface rocks either by precipitation or condensation. The following outline illustrates the disposal of the waters.

\section{Disposal of precipitation.}

I. Direct evaporation before absorption or run-off.

a. Evaporation of the water film from soil and rock surfaces, vegetation, etc.

b. Evaporation from undrained pools.

c. Evaporation from snow surfaces.

II. Absorption by vegetation.

a. Living.

b. Vegetable mold, etc.

III. Direct run-off (without previous absorption).

- IV. Absorption by soils and rocks.

The relative importance of the several methods of disposal will vary greatly according to temperature, humidity, vegetation, character of soils, and other related factors. In humid regions and with soils of average porosity the absorption by rocks and soils is by far

a These terms are used as defined by J. W. Powell, Mon. Nat. Geog. Soc., vol. 1, No. 1, 1895 , p. 1 . 


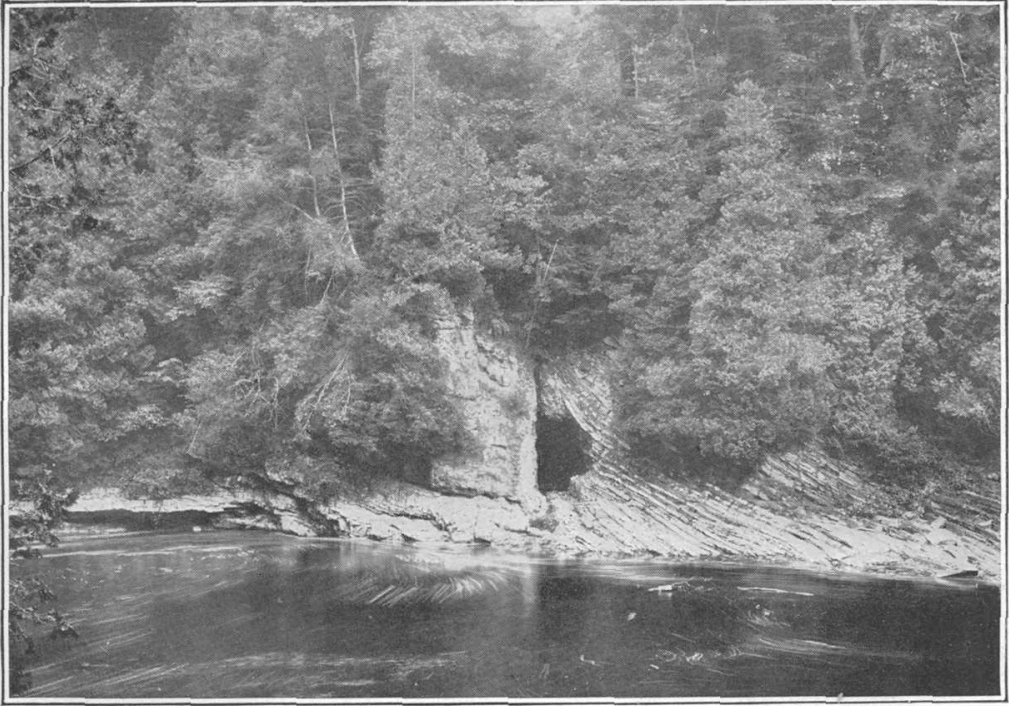

A. SOLUTION CHANNEL ON FAULT LINE.

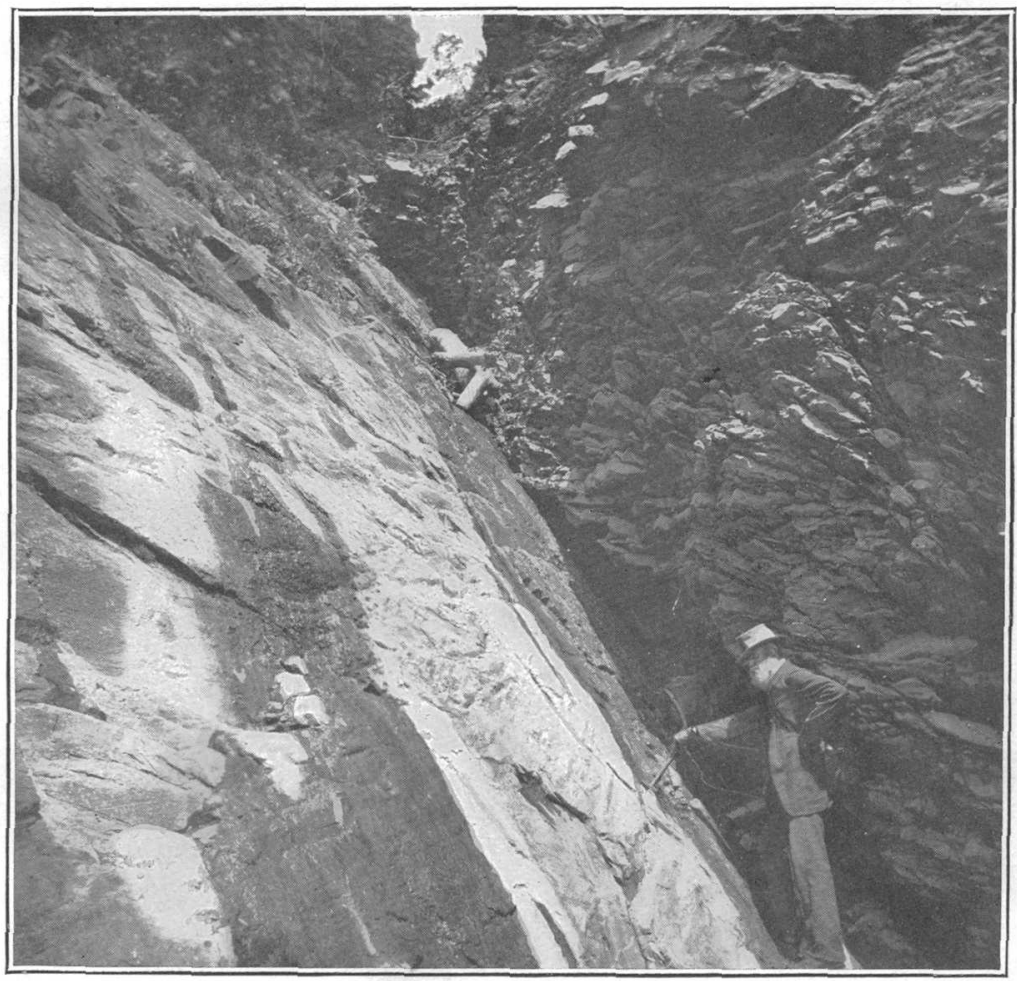

B. CRUSHED ZONE ON FAULT. 


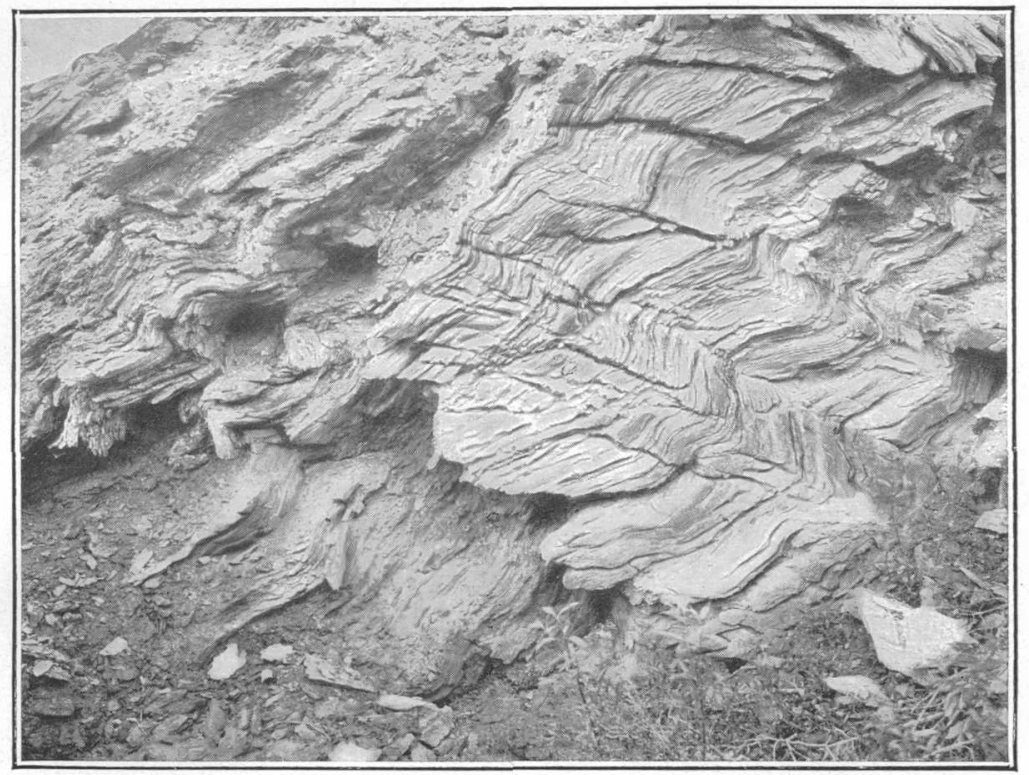

A. SCHISTOSITY PLANES.

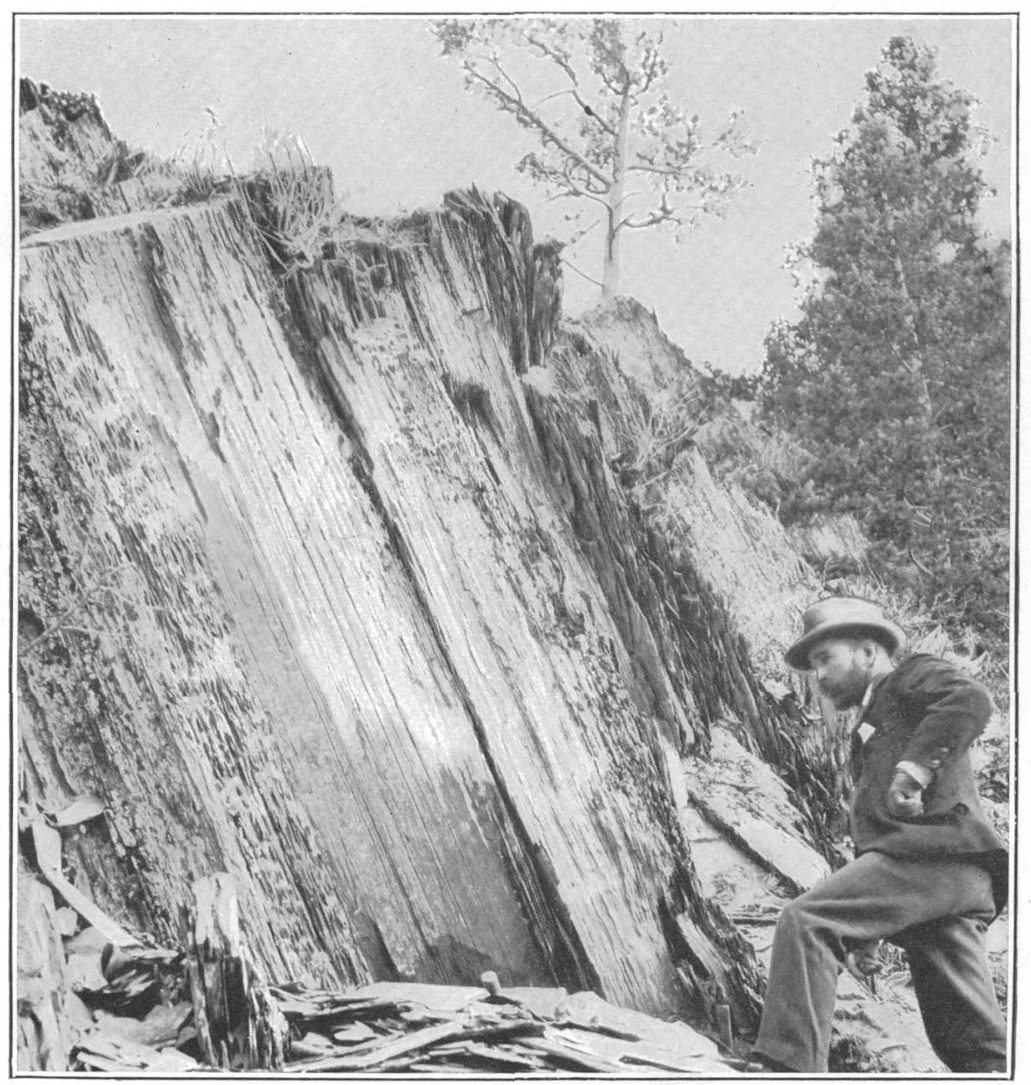

B. cleavage planes. 
the most important, probably accounting for at least 85 per cent of the precipitation. In certain sandy regions, as on Cape Cod, Long Island, it is probable that nearly or quite 95 per cent of the water enters the soil immediately, there being practically no direct run-off except on the rare occasions when rain falls on frozen ground or snow. In clayey regions and in areas of rock, especially where vegetation is very scarce, a large local and temporary run-off may result.

Any surplus of the water of condensation over that required to wet the surface of the ground and vegetation is taken up directly by the soil, there being practically no evaporation under the existing conditions. Ordinarily the amount so derived is small, but it may become of some consequence in certain mountainous regions, where direct condensation is sometimes sufficient to form little rivulets of water on the condensing surfaces.

Waters from lakes and streams.-One of the most common popular conceptions is that ground waters are derived either from neighboring or more remote lakes and streams. It is too well known to require more than the simple statement, however, that the movement of such water is normally toward and not away from the water bodies, the surfaces of which are below and not above the water table. It is only when there is some sudden rise of water in the lake or stream due to causes independent of local rainfall that the level becomes higher than the adjacent water table and-a landward movement takes place. These conditions are illustrated by fig. 1 . Such movements occur tempo-

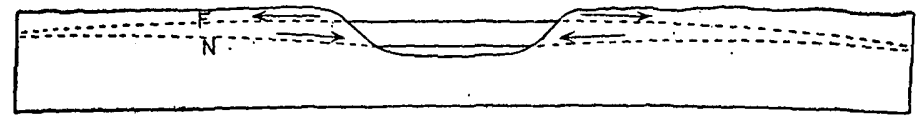

FIG. 1.-Section illustrating conditions governing movement of water away from streams or lakes. N, Normal position of water table; $\mathrm{F}$, position of water table during floods.

rarily during the flood period of rivers fed from mountain snows, etc., or in lakes supplied by such streams. Similar conditions exist where the torrents resulting from cloudbursts temporarily flood certain parts of our great deserts.

WATERS FROM THE OCEAN.

Contemporaneous absorption.-As in the case of rivers and lakes, the ground-water movement is ordinarily toward the sea, but occasionally, especially in estuaries, severe storms bank up the waters to a height of several feet above their normal level for a considerable length of time. At such times movements of salt water into the sand may occur, sometimes seriously affecting adjacent shallow wells.

$$
3698-B \text { Bull. } 310-08-2
$$


Other than under the above conditions, ocean water does not commonly penetrate inland. When the natural conditions are disturbed however, as when wells near the shore are heavily pumped, the water table may be sufficiently lowered to establish a reversed movement. Salt water also occasionally penetrates far inland where open solution channels in limestones-now abandoned by the streams which formed them-afford passages for it. Probably the most remarkable case of penetration by sea water is that at the so-called Sea Mills of Cephalonia in Greece, where a steady stream large enough to run a mill has from time immemorial left the sea and passed inland, finally disappearing into the porous limestone. ${ }^{a}$

The supposed causes of this phenomenon are discussed on page 30 .

Originally included sea water.-Sediments formed in the ocean include large quantities of sea water, the amount varying from 10 to 40 per cent or more of the bulk of the material according to its nature. Ordinary sands commonly hold about one-third of their volume. If the marine beds are lifted above sea level while still in an unconsolidated condition much of this water will drain out except when the beds are so warped in the process as to form troughs or when drainage is prevented by the presence of overlying impervious beds.

The Cretaceous deposits near Wilmington, N. C., afford a good example of included waters in beds not yet uplifted, flowing wells of salt water being obtained at many points, even beneath impervious clays which effectually prevent any present access of the sea water. The pressure comes from the meteoric waters entering at the outcrop near the inner edge of the Coastal Plain, and as the salt water is removed fresh water takes its place. Instances of salt wells turning fresh have been described by the writer in another paper. ${ }^{b}$ Perhaps the best illustration of included water in older and uplifted rocks is that afforded by the salt waters of the thick, open sandstones of the Carboniferous series of western Pennsylvania, the waters occuring under conditions which seem to preclude their access to any saltbearing beds.

WATERS FROMI THE ROCKS OF THE CRUST.

By waters from the lithosphere or crust are meant the originally combined or otherwise unavailable waters which have later been set free by physical or chemical exclusion. In their original form the waters are either primary (forming a part of the original minerals) or secondary (derived from absorption by some one of the methods outlined in the preceding sections).

\footnotetext{
${ }^{a}$ Crosby, F. W., and Crosby, W. O., The Sea Mills of Cephalonia: Tech. Quart., vol. 9, 1896, pp. 6-23. Fuller, M. L., Bull. Geol. Soc. America, vol. 18, pp. 221-232.

${ }^{b}$ Fuller, M. L., Instances of improvement of water in wells : Water-Sup. and Irr. Paper No. 160, U. S. Geol. Survey, 1906, pp. 96-99.
} 
Chemically excluded waters:-The chemically excluded waters are the originally combined waters which have been set free by chemical processes. As first formed numerous minerals are in the hydrated form, but later, usually through the influence of heat and pressure, lose the whole or part of their water. This process of dehydration commonly takes place only at considerable depths, and usually results from recrystallization or recombination due to metamorphism. In some cases the entire amount of water contained by the minerals is. excluded, but in others, as in some of the recombinations, only a part is driven out. Among the best illustrations of the processes are the exclusion of mechanically included waters by the crystallization of amorphous limestones as calcite, by the change of certain gypsums through metamorphic action to anhydrite, and by the change of peat and lignite to coal. The action is not solely deep seated, there being more or less extensive dehydration, especially of iron compounds, in regions where hot and dry seașons alternate with periods of rainfall. Van Hise attributes the red hematitic stains, colorings, etc., of the deserts of southern California and elsewhere to the dehydration of the iron from the limonite form. ${ }^{a}$

Since dehydration takes place mainly at considerable depths the water is not lost to the rock crust as a whole, but simply to the part undergoing alteration. Most of it passes upward into the more porous unaltered rocks, in which it may remain for an indefinite period.

Physically excluded waters.-The expulsion of secondary waters, including those derived from the process of dehydration in underlying rocks in the manner just described, as well as the included "waters of deposition," occurs mainly through the agency of pressure and heat. The exclusion by pressure is well illustrated by the violent expulsion of water along fault rifts during great earthquakes, an action which, although especially manifest at the surface, can hardly be confined to this zone, but must often occur between beds at considerable depths. The action of heat in expulsion will be most pronounced where water-bearing strata are penetrated by igneous intrusions, especially where ready escape for the steam or water into overlying beds is afforded by joint, fault, or other openings.

WATERS FROM 'THE CENTROSPFERE.

The waters from the centrosphere may be divided into those reaching the reservoirs in the crust by direct emanation or exclusion, and those reaching the upper crust indirectly through igneous intrusions. As was shown by Hoskins, ${ }^{b}$ rock pressure limits the occurrence of open

\footnotetext{
a Van Fise, C. R., Some principles controlling the deposition of ores : Trans. Am. Inst. Min. Eng., vol. 30, 1900, pp. 27-177.

${ }^{b}$ Hoskins, L. M., Flow and fracture of socks as related to structure: Sixteenth Ann. Hept. U. S. Geol. Survey, pt. 1, 18i, op. 845-875.
} 
cavities in ordinary rocks to depths under 10,350 meters, but rockinclosed, liquid-filled cavities can exist to an indefinite depth at which water and molten rock are miscible in all proportions. The volume of aqueous matter in the central magma is an unknown quantity, but it is acknowledged that practically all lavas contain material amounts of water, and while some, if not most of it, may be derived from the rocks through which the lavas have passed, a part is doubtless derived from the original magma. It is not improbable that as the cooling of the central magma progresses considerable amounts of water are given off into the overlying rocks. This and. the more common form of magmatic waters-that given off from igneous intrusions-together form, in the belief of many geologists interested in economic deposits, an important source of ore-depositing solutions. At any rate it may safely be said that it is often of great local importance.

\section{CONFINING AGENTS.}

In this discussion the confining agents in artesian systems are divided for convenience into bedded and jointed rocks. In the usual discussion impervious beds are ordinarily the only agents recognized, but observations made by a considerable body of field workers during the last four years has brought to light some new conditions of flow and has emphasized the importance of a number of factors that are seldom mentioned. The principal confining agents are as follows: .

I. Bedded rocks.

\section{Confining agents.}

A. Upper confining agents.

1. Impervious beds.

2. Stratification.

3. Friction.

4. Mineral crusts.

5. Frost zones.

6. Confined air and gas.

7. Fresh water.

8. Salt water.

B. Lower confining agents.

1. Impervious beds.

2. Stratification.

3. Friction.

4. Mineral crusts.

5. Frost zones.

6. Confined air and gas.

7. Fresh water.

8. Salt water.

9. Cementation.

10. Heat.

11. Pressure. 
II. Jointed and fractured rocks.

A. Upper confining agents.

1. Impervious hanging wall.

2. Impervious surface coverings.

3. Frost fillings.

4. Vein fillings.

5. Weathering products.

6. Converging walls.

7. Interrupted joints.

S. Sea water.

B. Lower confining agents.

1. Impervious foot walls.

2. Vein fillings (cementation).

3. Converging walls.

4. Interrupted joints.

5. Fresh water.

6. Sea water.

7. Heat.

8. Pressure.

BEDDFD ROCKS.

UPPER CONFINING AGENTS.

Impervious bed.-The term "impervious bed" is here used to designate a bed of stratified material through which water penetrates with difficulty-the sense in which it has been used in practically all previous discussions of artesian waters. In general it has been assumed that such a bed-relatively impervious as compared to the water bed-is essential to artesian flows, and it has been so shown in practically all figures illustrating artesian systems. As a matter of fact, however, it need not be absolutely impervious. In the words of Chamberlin," "a stratum that successfully restrains the most of the water, and thus aids in yielding a flow, is serviceably impervious." Clays furnish the best confining strata, being both impervious in character and free from open joints or other fractures that permit the water to pass through. Shales are generally accounted as second in value. Some limestones, as the Clinton of southwestern Ohio, are good confining agents, but most rocks of this kind are broken by joints that afford numerous points of leakage.

Stratification planes.-At several places. in Michigan and elsewhere flows have been procured from homogeneous sands. As has been explained in another report, ${ }^{b}$ the cause of the confinement may probably be found in the arrangement and shape of grains. All materials that afford flows of the nature described are stratified-in other words, they were deposited in layers, which, though composed of:

a Chamberlin, T. C., The requisite and qualifying conditions of artesian wells: Fifth Ann. Rept. U. S. Geol. Survey, 1885 , p. 138.

${ }^{b}$ Fuller, M. L., ILwo unusual types of artesian flow : Water-Sup. and Irr. Paper No. 145, U. S. Geol. Survey, 1905, pp. 41-45. 
material of uniform grain, were nevertheless laid down successively one over another as independent horizontal laminx. This process develops conditions that are more favorable to the transmission of water along the laminæ than across them, due in part simply to the lamellar arrangement. ${ }^{a}$ There is, however, another factor presentnamely, the irregularity of the shape of grains-which has probably considerable influence in regulating the flow of water through the sand. In sediments, such as gravel and sand, the particles no matter how uniform their size are not symmetrical in shape. One axis is almost sure to be longer than the other (fig. 2), and when deposition takes place the grains have a strong tendency to arrange themselves with their longer axes horizontal and to overlap one another to a greater or less extent, like the shingles on a house, though, of course, far less perfectly (fig. 3): Under such conditions it is clear that,

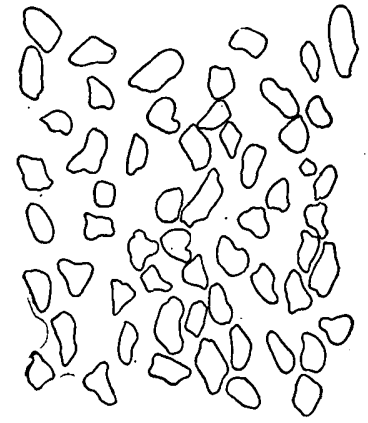

FIG. 2. - Form of sand grains.

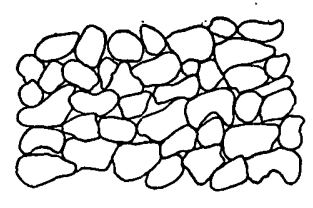

Fig. 3.-Arrangement of sand grains in stratified depoșits.

although the material is pervious and may hold large amounts of water, the passage of water across the planes of stratification will be difficult, at least as compared with its passage along those planes. A well that enters such material will afford an upward path for the water that is easy as compared with its passage through stratified material of the character described, and a flow will often result.

Friction.-Friction alone seems to be competent under certain conditions to produce the necessary confinement, especially where the reservoir is fed at the bottom. If, for instance, water should enter at the bottom of a thick bed of fine, uniform, and structureless sand under a head sufficient to lift it 100 feet through the sand it would rise in a pipe tapping it at the bottom to a height greater than its level in the sand outside, the difference being determined by the relative amounts of friction in sand and pipe. This factor may be as common in producing flows as the factor of stratification described above.

\footnotetext{
a This overlapping of grains has been descriped by W. O. Crosby in his discussions of "hard-packed" sand in glacial deposits at Clinton, Mass. (Tech. Quart., vol. 17, 1904, pp. 61-62 and 67-70.) Although such sand is so deposited or "packed" that it strongly resists the advance of the drill, it nevertheless absorbs large quantities of water.
} 
Mineral crusts.-When thé water table is in porous materials and is fairly constant in level, mineral matter is frequently deposited along the upper surface, forming a sort of crust. A number of such crusts have been noted in the drift deposits of Michigan, Minnesota, and other States, while they are very common indeed in many of the desert regions. In Minnesota the crusts are of both iron and lime, and some of them are several inches thick. The iron crusts have the appearance of bog ore, resembling the similar deposits in Michigan. ${ }^{a}$ As long as the water table remains stationary the crust has no effect, but whenever a rise takes place, due to rainfall entering at higher points, the crust holds back the water with the result that a material artesian pressure is quickly developed. (See fig. 9, p. 41.)

In the desert regions the crusts, known as "caliche," are composed mainly of calcium carbonate and occur at various levels, ranging from 3 or 4 feet below the surface to considerable depths. These crusts appear to be of different origin at different localities, being due in part to the evaporation of waters brought up by capillarity, as postulated by Blake; ${ }^{b}$ in part to precipitation from underground waters, by reason of the loss of carbon dioxide on the release of pressure, as suggested by Lee; ${ }^{\circ}$ and in part to downward leaching and concentration of rain waters, as urged by R. H. Forbes. ${ }^{d}$ Like the crusts previously mentioned, they may serve as confining beds whenever there is any rise of the water table due to rainfall at higher points.

Frost zones.-The action of frost zones, such as frozen soils, is very similar to that of the crusts just described. Such frozen crusts form at the bases of gentle slopes along valleys, or wherever the water table comes to the surface, and extend back under the high ground to points where the water is no longer within reach of frost. Where the slope is gentle this may be some distance. The soil farther back not being saturated is often not frozen at all, especially in sandy and other welldrained materials. Under such conditions rain water not uncommonly sinks downward in the unfrozen region and raises the water table, with the result that the pressure is transmitted beneath the frozen soil. If the frozen crust is penetrated at such times the water will flow at the surface. (See fig. 9, p. 41.)

Confined air and gas.-While waters rising under the influence of gas pressure are not regarded as artesian, air and gas can not be excluded from the list of confining agents. Water is just as effectually

a Leverett, Frank, Flowing wells and municipal water supplies in the southern portion of the Southern Peninsula of Michigan: Water-Sup. and Irr. Paper No. 182, U. S. Geol. Survey, 1906, pp. 8-9.

${ }^{b}$ Blake, W. P., Caliche of southern Arizona : Trans. Am. Inst. Min. Eng., vol, 31, 1901, p. 220 .

- Lee, W. T., Underground waters of Salt River valley, Arizona: Water-Sup. and Irr. Paper No. 136, U. S. Geol. Survey, 1905, pp. 1.07-111.

${ }^{d}$ Quoted by Lee, ibid., p. 110. 
prevented from reaching the crest of a gas-bearing anticline by the gas pressure as if an impervious bed intervened, and one is as truly a confining agent as the other. Confined air may likewise limit the rise of water in dome-like caverns in limestone, while confined air in earth, when prevented from upward escape by frozen or saturated soil zones, often acts temporarily as a confining stratum.

Fresh water.-The action of fresh water as a confining agent can not be better described than in the words of Chamberlin : ${ }^{a}$

Paradoxical as it may seem, water itself may form a confining agent. * * * If the water between the well and fountain head is actually higher than the latter, it will tend to penetrate the water-bearing stratum, so far as the overlying beds permit, and will, to that extent, increase the supply of water seeking passage through the porous bed, and will, by reaction, tend to elevate the fountain head, if the situation permit. I conceive that one of the most favorable conditions for securing a fountain is found when thick semiporous beds, constantly saturated with water to a greater height than the fountain head, lie upon the porous stratum, and occupy the whole country between the well and its source. This is not only a good, but an advantageous, substitute for a strictly impervious confining bed. Under these hydrostatic conditions, limestone strata reposing on sandstone furnish an excellent combination.

It should be noted, however, that although an impervious cover is not postulated the water bed is assumed to be relatively more porous than the confining stratum, and no recognition is made of flows from uniform materials, as described on pages 21, 22. The latter, however, adds even more emphasis to the importance of water as a confining agent than did the conditions described by Chamberlin.

Sea water. - When porous deposits extend outward beneath the sea, as along sandy coasts, the fresh waters moving from the land rise from below against the pressure of the sea water. As sea water has a specific gravity of approximately 1.027 it will hold up a column of fresh water of materially greater length, and when the head of the fresh water is less, as is frequently the case, than the excess of weight of the sea waters, the latter may act as effective confining agents. (See p. 43.)

\section{LOWER CONFINING AGENTS.}

What has been said of the upper confining agents applies in many instances with equal force to the lower confining agents. The under bed, like the upper, may be any "bed that successfully retains most of the water," whether absolutely impervious or not. Stratification planes may limit the downward.penetration of the water in thick beds as it does the upward movement, and friction may produce the same result, especially in slightly inclined beds of great extent. Mineral crusts are more common as an upper restraining agent than

"The requisite and qualifying conditions of artesian wells : Fifth Ann. Rept. U. S. Geol. Survey, 1885 , pp. $138,140$. 
"as a lower, but cases undoubtedly occur where the water is confined between two such layers. Water is found between frozen layers of soil in Alaska. Confined air often acts temporarily as an under confining agent, as in the saturated zones upheld by the air of soils during heavy downfalls of rain, and confined gas may possibly act similarly. Previously absorbed fresh waters, by saturating the deeper rocks, limit the depth of circulation of waters entering subsequently. Sea water is even more important as an underlying stratum than as an upper confining layer. In addition to the preceding agents, which act both as upper and lower confining agents, general cementation, heat, and pressure are effective factors ir limiting the downward penetration of water under certain conditions.

Cementation.-Cementation is the process by which the grains of sedimentary rocks are bound together and the intervening pores filled by the deposition of mineral matter from infiltrating solutions. Unlike the formation of crusts, this deposition does not result from evaporation, but from the supersaturation of solutions at depths far below the water table. It is not usually limited to a single layer, or point, but is a general process affecting large bodies of rock over wide areas. The conversion of open porous sandstones to dense impervious quartzites by the deposition of silica is perhaps the best example of the process, which is notably efficient in limiting the downward penetration of waters.

Heat.-It has often been assurned that the circulation of water, owing to its supposed conversion into steam, is limited to relatively moderate depths, but it can be readily shown that the rise of the boiling point due to increased pressure ordinarily more than counterbalances the increased heat at great depths, and that under any of the usually accepted rates of increment, change to steam will not take place. When water approaches uncooled. igneous intrusions that lie at shallow depths, however, conversion to steam may occur, and the downward penetration of the water may be stopped. This is probably a common factor of limitation in igneous regions and may possibly act in regions where the temperature gradient is particularly high.

Pressure.-Pressure, as shown by Hoskins, ${ }^{a}$ closes all ordinary cavities at about 10,000 meters and imposes an effectual limit to the penetration of free water, although rock-inclosed, liquid-filled cavities can exist to a depth at which water and rocks are miscible in all proportions. As a matter of fact, pressure is probably rarely an important factor in limiting the penetration of water in the unaltered bedded rocks because of their essentially superficial occurrence.

a Hoskins, L. M.. Flow and fracture of rocks as related to structure: Sixteenth "Ann. Rept. U. S. Geol. Survey, pt. 1, 1896, pp. $845-875$. 
JOINTED ROCKS.

\section{OPPER CONFINING AGENTS.}

Impervious wall.-In the same way that an impervious overlying bed is a leading restraining agent in bedded rocks the impervious hanging wall of an inclined joint is a prominent confining agent in jointed rocks. Like the former, it may not be absolutely but only relatively impervious, but owing to the fact that joints are mainly developed in dense or massive rocks, especially in the fine-grained types, the joint wall is on the average considerably more impervious than the cap rock in bedded formations.

Impervious covering on surface.-This is a very common restraining agent in jointed or fissured rocks. It is especially well shown in the extensive "lake-bed" region of southeastern Michigan, where artesian water, under pressure enough to lift it to the surface, is confined over considerable areas in jointed and fissured limestone, etc., by the overlying clayey till and "lake-bed" deposits. ${ }^{a}$ The numerous flows from granite beneath alluvium in valleys in the Piedmont area of the Southern States is due to the same causes. (See figs. 11 and 14 , pp. $41,42$.

Frost fillings.-In winter water freezes almost as fast as it seeps out at the surface, and it is not uncommon to find that joint openings through which water is ordinarily rising are frozen solid to some distance from the surface. The ice under such conditions may present an effective barrier to the water pressing upward from below.

Vein fillings. - Water coming up from below and carrying an excess of mineral matter in solution not infrequently deposits it in the openings near the surface, sometimes closing the joint openings as completely as they are closed by ice. Mr. G. O. Smith has described such fillings and considers them the probable confining agents that give rise to the artesian flows from the crystalline rocks in parts of New Hampshire and Maine. ${ }^{b}$

Weathering products.-The usual action of the weather is to widen the joints and other partings, but occasionally, where the circulation is slight, the clayey products of decomposition are not entirely removed, but collect in the joints and other available openings, sometimes clogging them sufficiently to render them effective obstacles in the path of uprising waters. The closing of joint passages due to the expansion resulting from the process of hydration in rocks undergoing weathering is also a possible factor in restraining underground water circulation.

${ }^{a}$ Fuller, M. L., Two unusual types of artesian flow: Water-Sup. and Irr. Paper No. 145, U. S. Geol. Survey, 1905, pp. 40-45.

${ }^{b}$ Water resources of the Fortsmouth-lork region, New Hampshire and Maine: WaterSup. and Irr. Paper No. 145, U. S. Geol. Súrvey, 1905, pp. 120-128. 
Sea water-Because of its greater density, sea water exerts in jointed rocks, as in bedded rocks, a decided restraining influence on uprising fresh waters, even when their head is somewhat higher than sea level, and it is a possible factor in affording the confinement necessary for some of the flows from jointed rocks when near sea level.

Converging walls.--The converging of the joint walls near the top may be due to mineral deposition on the sidès, to expansion of the wall rock due to weathering, to local pressure developed through faulting or readjustments of the joint blocks, or to the relative absence of solution as compared to that at greater depths. A contraction of the opening sufficient to exert a decided restraining influence on the underground waters may result from any of the causes indicated.

Interruptions of joints.-Joints are not of unlimited extent, although some of the master joints may be miles in length. A joint may terminate either by gradual contraction and disappearance or by ending abruptly against an intersecting joint or other plane. This is especially true of intersecting horizontal and vertical joints, the latter frequently ending abruptly against the former. As most horizontal joints $\mathrm{a}^{-}$less open than vertical joints, the termination is at many places $\mathrm{s}$. as to prevent circulation beyond it.

\section{LOWER CONFINING AGENTS.}

The lower confining agents are not greatly different from the similar agents in bedded rocks or from the upper confining agents in jointed and fractured rocks already described. The impervious foot wall is comparable with the impervious hanging wall and is subject to the same qualifying statements. Frost filling and weathering play little or no part in fixing the lower limit of penetration, but vein fillings are as likely to occur at considerable depths as at the surface, and are probably not infrequently a factor of importance. The convergence of walls and the interruption or termination of joints are doubtless of even greater importance than as upper confining agents. Fresh and sea waters limit the downward penetration as in the bedded rocks, and, similarly, heat and pressure may locally play important parts.

\section{NATURE OF ARTESIAN CIRCULATION.}

Artesian circulation takes place by virtue of the variations in the pressure to which the water is subjected in different parts of its reservoir. By definition of the artesian principle (p. 7 ) all factors except hydrostatic pressure are excluded as determining causes of circulation. There are, nevertheless, a number of modifying agencies which in some cases exert a powerful influence on the water head or movement. The more important of the controlling and modifying factors may be summarized as follows: 
I. Primary factor.

\section{Factors in artesian circulation.}

A. Gravity.

II. Modifying factors.

A. Factors mainly affecting pressure.

1. Barometric variątions.

2. Temperature rariations.

3. Density of waters.

a. Variations cue to temperature.

b. Variations due to dissolved salts.

c. Variations due to suspended solids.

4. Height of adjacent water levels.
a. Water table.
b. Neighboring water bodies.
c. Levels dependent on floods.
a. Levels dependent on tides.
e. Levels depeudent on winds.

5. Rock pressure.

B. Factors mainly affecting movement.

1. Porosity.

2. Size of grain or openings.

3. Temperature.

\section{PRIMARY FACTOR,}

Gravity.-The leading factor in artesian circulation is gravity, from which fact it follows that (disregarding friction) the pressures in the opposing arms of an artesian system will be proportional to the heights of the respective water columns, while the effective head will be determined by the difference in the two. The hydrostatic pressure dependent on gravity is the sole recognized cause of artesian pressure as the term is here used (p. 7 ), although its action is modified in many ways by the qualifying factors considered below.

The operation of the ordinary hydrostatic law is limited to appreciable openings. According to Daniel ${ }^{a}$ such openings, which are known as supercapillary and.include joints, faults, bedding planes, some fissility planes, the pores of sandstones, etc., have for their minimum limit a diameter of $0.508 \mathrm{~mm}$. in tubular passages and a width of $0.254 \mathrm{~mm}$. in sheet openings of the joint or bedding-plane types.

\section{MODIFYING FACTORS.}

The factors which modify the pressures resulting from gravity may be divided into those which cooperate directly with the latter in determining the hydrostatic pressure, and those which primarily affect the movement of the water and only incidentally influence the pressure. ${ }^{b}$

a Daniel, Alfred, Text Book of Physics, 3d ed., 1894, pp. 277, 316

$b$ For an extended discussion of the factors giving rise to fluctuations of water level, see Veatch, A. C., Fluctuations of the water level in wells: Water-Sup. and Irr. Paper No. 155, U. S. Geol. Survey, 1906. 


\section{FAC'TORS MAINLY AFFECIING PRESSURE.}

\section{BAROMETRIO VARIATIONS.}

For each locality there is a normal barometric pressure dependent upon elevation, latitude, and distance from the ocean. This, however, is subject to many influences, both cyclic and irregular, which materially modify the ultimate pressure. The barometric factors may be classified as follows:

Barometric factors.

I. Constant factors.

1. Elevation.

2. Latitude.

3. Distance from ocean.

II. Variable factors.

1. Cyclic.

a. Diurnal variations.

b. Seasonal variatious:

c. Variations due to solar movements.

d. Variations due to lunar movements.

2. Irregular.

a. Atmospheric disturbances.

b. Cyclones.

c. Storms.

d. Cloudiness.

3. Topographic surtoundings (independent of altitude).

Although many of the factors are very weak in their action all are measurable, and, with the exception of solar and lunar movements, cloudiness, and topography, all are known to exert an appreciable influence on wells. In some instances the resultant effects appear to be far grëater than those that would be due to the actual differences in pressure at the point of observation. The cause of this is as ycit unknown, but it is possible that it may prove to be related to those producing the remarkable seiches of the Great Lakes, some of which are marked by a change of water level as great as 6 feet. It is not improbable that under favorable conditions all the variations noted have a material effect on underground waters. The manifestations are most noticeable at periods of low barometer and include increase of head, increase of flow, muddiness, and discoloration.

\section{TEMPERATURE VARIATIONS.}

Temperature acts on artesian circulation through its influence on the viscosity of the water, through the expansion and contraction of included air or gas, by variations in the pressure of confined air or gas upon water surfaces, and by its influence on the density of the artesian waters. Of these viscosity mainly affects the water move- 
ment directly, although it incidentally affects the head through its influence on friction. The expansion and contraction of included gases has a direct affect on pressure and head. The influence of temperature on density is considered below.

\section{DENSITY OF WATERS.}

Variations due to temperature.-Water expands about 4.3 per cent when heated from its point of greatest density $\left(39.2^{\circ}\right)$ to the boiling point and gives rise, in the case of long columns, to notable variations of volume and density. The difference in weight of cold and warm columns, and the resultant increase in the length of the latter, has been cited as an important factor in deep circulation, especially at the Sea Mills of Cephalonia. ${ }^{a}$. The considerable streams which leave the ocean at this point and disappear into limestone crevices at sea level can only regain the surface at equal or hiigher levels. This result can apparently be attained only through the action of temperature or some other force that affects the density.

Variations due to dissolved salts.-Besides temperature, the weight of water depends largely upon composition, the weight increasing materially according to the amount of mineral matter in solution. Sea water has a specific gravity of 1.027 as compared with 1 , the specific gravity of fresh water, from which it follows that a column of salt water 100 feet in height will support nearly 103 feet of fresh water. Even allowing for only relatively slight variations in density we have sufficient differences in pressure to produce circulation. This is thought to be a more effective cause than temperature in producing the circulation at the Sea Mills of Cephalonia mentioned above. ${ }^{b}$

Variations due to suspended solids.-The action is similar to that oi dissolved mineral matter, but is usually much more pronounced. It is best illustrated by certain phenomena exhibited in the jet process of well drilling, in which clear water is forced under pressure down a small tube inside a larger one, the materials detached by the current being carried to the surface in the space between the inner pipe and the outside casing. When the pressure is removed from the small tube the water is often found to rise in it materially above the height of the well and to flow for some moments at elevations several feet above the surface, the water between the inner and outer tube sinking at the same time. This peculiar action seems to be due entirely to the high density of the mud- or sand-laden waters in the large tube as compared with the clear and lighter water in the inner pipe.

\footnotetext{
a Crosby, F. W., aud Crosby, W. O., Tech. Quarterly, vol. 9, 1896, pp. 6-28.

b Fuller, M. L., Conditions of circulation at the Sea Mills of Cephalonia: Bull. Geol, Soc. America, vol. 18, pp. 221-232.
} 
Water table.-The height of the water table over any point in an artesian system may exert a.material influence on the pressure. In fact, this may be a far more important factor than the pressure transmitted from the more remote catchment area. This action has been discussed in greater detail on page 24 .

The level of the water table is controlled by a great number of factors, among which may be mentioned the amount of rainfall, the amount of evaporation, and the porosity of materials. The ground water does not usually respond at once to the rainfall, owing to the length of time that the water requires to penetrate the unsaturated upper materials; nor does the rise correspond in amount to the precipitation, because of losses by evaporation, absorption by vegetation, and the retention of a portion in the unsaturated zone. In very heavy rainfall a saturated zone may be formed at the surface, constituting a temporary perched water table, when the main water table may be affected almost immediately owing to the transmission of pressure by the air confined beneath the saturated layer.

Neighboring water bodies, etc.-The level of lakes and streams is commonly a function of the height of the ground water in the vicinity, but sometimes the reverse is true and the ground-water level becomes a function of the level of the water bodies on the surface. The latter may also in some cases influence to considerable extent the pressure on underlying confined waters.

The effects of surface water bodies on the underground waters may be summarized as follows:

\section{L'ffects of height of surface water bodies on underground waters.}

I. Changes of ground-water levels.

1. Changes due to variation of level of surface streams receiving groundwater discharge.

2. Changes due to movements away from surface water bodies.

II. Variations of pressure on confined waters.

1. Changes due to communication between surface and underground water bodies through intervening beds.

a. Communication through joints and other passages.

b. Communication through the body of the intervening beds.

2. Changes due to transmission of pressure through intervening beds.

3. Changes due to plastic deformation.

The cause of the changes of ground-water levels resulting from variations in the height of the surface water bodies which receive the underground drainage is apparent. When such bodies are low the movement of ground waters is accelerated and the water table depressed, while when they are high the underflow is slackened and the water table elevated. 
In pronounced rises of the water levels in surface bodies due to floods, tidal fluctuations, banking of waters under the action. of strong winds, or to other causes arising from conditions developing outside of the immediate area affected, the ground water is no longer able to issue at its normal level. In fact the rising waters act primarily as a dam, raising the level of discharge of the ground waters and ponding them up like the backwater behind an artificial dam. When the rise is more rapid than in the inflowing ground water an actual outward movement from the surface body may take place, producing a corresponding rise of the ground water.

Another effect of the rise of surface waters is a downward penetration of such water (due to the increased pressure) through the underlying retaining beds into more porous water beds below. This takes place in part through joints and similar passages, which are present even in soft, unconsolidated clays, and in part, perhaps, through the body of the material itself. In either case a very slight movement is sufficient to produce a pronounced rise in the waters of wells. Considering an area 1,000 feet square, a downward water movement of only one one-thousandth of a millimeter through a clay or other capping would be equivalent to a rise of approximately 25 feet in a single well, or 1 foot in 25 wells.

The transmission of pressure through the so-called impervious beds is probably sometimes a factor of artesian head, even though no movement of water through the beds takes place. Some quicksands, although they will yield little or no supplies to a well, often carry from 30 to 50 per cent of water, some of which is in supercapillary openings and hence is capable of transmitting hydrostatic pressure even when motion is prevented by excessive friction (using the term in its broader sense to include the resistance of inertia as well as the resistance to motion).

Still another result, which may be more common than is usually suspected, is the increase of pressure on confined waters, due to the plastic deformation of impervious beds under the varying loads resulting from changes in the water level of overlying streams, lakes, or the sea. This is especially noticeable in wells along the sea coast, which commonly fluctuate with the tide, even though the water horizon lies deep below the surface and is separated from it by thick beds of impervious clays, etc. The figures applying to the downward water movement in the preceding paragraph are equally applicable. to deformation and emphasize the slight amounts necessary to account for the observed fluctuations in wells. 
ROCK PRESSURE.

In addition to the deformation of the nature described in the preceding paragraph, pressure may be exerted by virtue of the. weight of the overlying materials alone. This is probably not a common factor, but extensive sinkings of the ground have followed the pumping of water from mines and the withdrawal of the support afforded by hydrostatic pressure, indicating that the rock pressure on the water must have been considerable, at least locally.

In the process of warping and folding the pressure of the rocks on the waters in their joints or other openings may often be important, especially when the disturbance is accompanied by faulting. Considerable quantities are excluded from such openings during earthquakes, and it is probable that the action underground is of much greater extent than the surface manifestations.

\section{FACTORS MAINLY AFFECTING WATER MOVEMENTS.}

The principal factors affecting. underground water movements are porosity, size of grain or openings, and temperature. The first and second are factors of capacity, while all three are factors of friction. Their action is not wholly on movement, but through friction they have a decided, though indirect, influence on pressure. From the formula of velocity as computed by Allen Hazen ${ }^{a}$ the following expression for loss of head is obtained: $h=\frac{v l}{c d^{2}(.70+.03 t)}$.

In this formula $h$ is the loss of head, $v$ the velocity in meters daily, $l$ the distance through which the water passes, $c$ a constant factor, approximately $1,000, d$ the effective size of grain in millimeters, and $t$ the temperature on the centigrade scale. For velocity the formula becomes:

$$
v=c d^{2} \frac{h}{l}(.70+.03 t)
$$

From these formulæ it appears that high porosities, large grains; and high temperatures all accelerate water movement. ${ }^{b}$

\section{REQUISITES OF ARTESIAN FLOWS.}

Having outlined the more important conditions bearing on the occurrence and movements of underground waters, we are in a position to discuss the controlling factors of artesian flow. In doing this it is necessary to point out some of the objections to certain of the commonly postulated requisites.

a Some physical properties of sands and gravel: Rept. Massachusetts State Board of' Health, 1892, p. 541 .

$b$ For a detailed description of the action see paper by C. S. Slichter on The motion of underground waters: Water-Sup. and Irr. Paper No. 67, U. S. Geol. Survey.

3698-Bull. 319-08-3 
Since the appearance in 1885 of the paper of T. C. Chamberlin on the "Requisite and qualifying conditions of artesian wells" $a$ a single set of requisites has, with one or two exceptions, been followed by writers of underground water papers. These, in brief, are as follows: (1) A pervious stratum to permit the entrance and the passage of water; (2) a water-tight bed below to prevent the escape of water downward; (3) a like impervious bed above to prevent the escape upward, for the water, being under pressure from the fountain head, would otherwise find relief in that direction; (4) an inclination of these beds, so that the edge at which the waters enter will be higher than the surface at the well; (5) a suitable exposure of the edge of the porous stratum, so that it may take in a sufficient supply of water; (6) an adequate rainfall to furnish this supply; and (7) an absence of any escape for the water at a level lower than the surface at the well.

There is one very serious objection to the requisites outlined above, namely, they apply only to a single class of flows--those from stratified rocks-and neglect not only flows from other varieties of rock, but even other types of flow from the same rocks. There are, moreover, many exceptions to the postulated requisites, which, taken in connection with the limitations mentioned, make new and more comprehensive definitions desirable. Some of the objections to the requisites are mentioned below.

Pervious stratum.-A pervious stratum, although a common form of reservoir, is seldom essential to artesian flows. In addition to the porous stratum postulated by the first requisite, flows may be obtained from lamination, bedding, cleavage, and shearing planes, from solution passages and mechanically eroded reservoirs, from vesicular zones in igneous rocks, from irregular joint and fault fractures, and from vein and igneous contacts. Metamorphic and igneous, as well as stratified rocks not only may, but actually do, yield flows at a large number of places; at many others the water falls only a few feet short of the surface; while in practically all wells the waters rise materially when encountered-that is, are truly artesian.

With the exception of the vesicular lavas the sources of water mentioned are not in the nature of beds, but are in the form of actual openings, a type of passage not recognized in the older requisites.

Impervious bed below.-In view of the nature of the reservoirs mentioned in the preceding paragraph and discussed in greater detail on pages $8-15$ it is apparent that the second requisite-the impervious underlying stratum-loses much of its force. Such impervious 
beds are, it is true, adjuncts to many flows in stratified rocks, but numerous other agents may serve the same purpose. In bedded rocks the following may be mentioned: Stratification, friction, mineral crusts, frost zones, confined air and gas, fresh or salt water, cementation, heat and pressure. In jointed and fractured rocks impervious foot walls, vein fillings, converging walls, interrupted joints, fresh and salt water, heat and pressure are the most important. Discussions of the agents in bedded rocks will be found on pages $24-25$ and of jointed and fractured rocks on page 27 .

Impervious bed above:-The objections to the postulation of an upper impervious bed are similar to those of the lower confining bed just enumerated. In the bedded rocks the following, in addition to the postulated impervious stratum, may serve as confining agents: Stratification, friction, mineral crusts, frost zones, confined air and gas, fresh water, and sea water. In the jointed and fractured rocks the impervious hanging wall, impervious surface coverings, frost and vein fillings, weathering products, converging walls, interrupted joints, and sea water may be mentioned in addition. For a discussion of these agents see pages 21-24, 26-27.

Inclination of beds.-Inclination of the water-bearing bed, while a common factor of artesian flows, is by no means essential. At many places water appears to penetrate lenses of sandstone in rocks, like those of the Carboniferous of Pennsylvania, through joints and similar openings, and flows may be obtained independent of any inclination of the bed affording the water. The same is true of the horizontal beds yielding flows by virtue of the opposition of the stratification planes to upward movements, as described on page 22. Joint and solution passages also afford artesian flows independent of any inclination at the point penetrated.

In both bedded and crystalline rocks the pressure must of course be transmitted from connecting passages or other water reservoirs at higher levels, but the supply itself does not necessarily come from a higher level, since besides the downward moving meteoric waters, sea waters, waters chemically or physically excluded from the crust, and waters excluded directly from the centrosphere or indirectly through magmatic intrusions all furnish supplies. These sources are discussed on pages 17-20.

Outcrop of porous stratum.-The postulated suitable exposure of the edge of the porous stratum so that it may take in a sufficient supply of water, though a common, is likewise far from an essential factor of artesian flows. The horizontal sandy beds from which the flows are obtained in Long Island and Michigan, as described on page 22, nowhere outcrop, the water.penetrating directly downward through the overlying layers. It is believed that in many other places the water and pressure are communicated to the deep-lying por- 
ous beds through joints rather than from remote outcrops. Moreover, throughout extensive areas of the Silurian, Devonian, and Carboniferous rocks in Pennsylvania, West Virginia, and Ohio, in the areas underlain by Cretaceous beds near Fort Monroe, Va., in the region about Wilmington, N. C., and in many lesser areas elsewhere; the deep artesian. waters appear to represent originally included sea waters and not waters entering at the outcrops. Other sources, including waters derived from the crust by chemical or physical exclusion or by direct or magmatic exclusion from the centrosphere, may furnish artesian supplies independent of the conditions of outcrop. (See pp. 17-20.)

Adequate rainfall.-Dince the salt waters of the Carboniferous and Coastal Plain rocks just described, as well as magmatic waters, are actually derived over extensive areas from sources other than rainfall, it is clear that rainfall should not be regarded as an absolute requisite to artesian flow.

Points of escape.-There are very few artesian systems in which there is not more or less leakage. In the thicker and more persistent beds the leakage is often sufficient to insure circulation for long distances from the outcrop. Thus, in the Cretaceous beds beneath Charleston, S. C., and Savannah, Ga., fresh water has replaced salt water at least as far as the seacoast, or over a distance of more than 100 miles from their outcrop. At Fort Monroe, Va., and at Wilmington, $\mathrm{N}$. C., on the other hand, there appears to be but little leakage, and the fresh water circulation is much less extensive, only salt water being obtained at the localities mentioned. The absence of leakage appears to have determined the presence of salt waters in the oilbearing rocks of Pennsylvania and elsewhere.

In order that leakage may prevent flows, it must take place near the point at which the water horizon is tapped. Chamberlin and others have shown that its influence is limited, and the requisites should therefore postulate the absence of near-by leakage rather than the entire nonoccurrence of leakage.

\section{ESSENTIALS OF ARTESIAN FLOWS.}

The essentials of artesian flows, as recognized by the writer, are as follows :

1. An adequate source of water supply.

2. A retaining agent offering more resistance to the passage of water than the well or other opening.

3 . An adequate source of pressure.

The first requisite is not made specific as regards source, because, as has been pointed out, artesian waters are not derived from a single but from a variety of sources. The second requisite-the retaining 
agent-may be a stratum, a vein or dike wall, a joint, fault, or other fracture plane, a water layer, or some one of a variety of other agents. (See pp. 20-27.) The presșure, although primarily due to variations in level in the different parts of the artesian system, may be traismitted in so many ways and is subject to so many modifying factors that the postulation of a specific cause is impracticable.

\section{MODIFYING FACTORS.}

It is believed that the three factors stated in the preceding paragraph are all that can be considered as essential to artesian flows; all other postulated requisites being in reality modifying or accessory rather than essential factors. These secondary factors may be classified as follows:

Secondary factors of artesian flows.

I. Hydrostatic factors (relating to pressure and morement).

1. Factors mainly affecting pressure.
a. Barometric pressure.
b. Temperature.
c. Density.
d. Rock pressure.

2. Factors mainly affecting movement.
a. Porosity.
b. Size of pores or openings.
c. Temperature.

II. Geologic factors (relating to reservoir).

1. Character of reservoir.

2. Retaining agents.

3. Structure of reservoir.

t. Topographic conditions.

5. Conditions relating to supply.

a. Catchment conditions.

b. Condition of underground feed.

6. Conditions of leakage.

The action of the various factors has already been indicated in connection with the foregoing discussion and no further statements are necessary.

\section{TYPICAL ARTESIAN SYSTEMS.}

In closing attention may be called to a number of the more common types of artesian systems. The artesian basin is the one most commonly figured, but in reality it is far less common than the artesian slope. Artesian flows from uniform horizontal beds appear to be common in many places, especially in the drift deposits of Michigan, but the areas of such flows in a single locality are limited. Flows from bedding planes appear to be not infrequent in the denser rocks, in which the beds themselves are not porous, but they depend on local conditions, and the flows can seldom be predicted. Flows 
from solution passages appear to be fairly common, notwithstanding the local character of the passages. The necessary confinement doubtless results from constrictions of the openings due to local zones of relatively insoluble rock, to clogging by débris entering through sinks, to the caving of the walls, to the accumulations of silt in the more sluggish passages, etc. Flows from lamination planes appear to occur in certain shales and slates, while joints furnish one of the most widely prevalent types of artesian systems in the country. In fact practically all crystalline rocks, both igneous and metamorphic, as well as the jointed types of sedimentary rocks, contain water under strong artesian pressure; and while flows are not abundant they are found at short intervals throughout the Piedmont Plateau of the eastern United States and will doubtless eventually be discovered at many other points where such rocks occur at the surface.

The following diagrams will serve better than descriptions to indicate the nature of some of the more common artesian systems.

ARTESIAN BASIN.

The section shown in fig. 4 presents a set of conditions that occur in typical form in the Dakota sandstone basin.

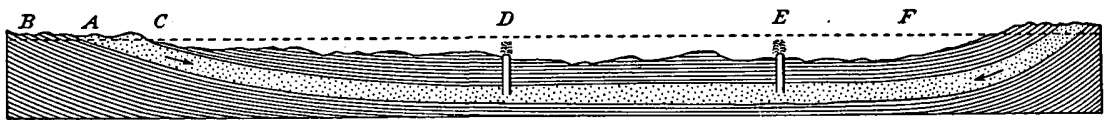

Fig. 4.-Section of an artesian basin. A, Porous stratim; $B, C$, impervious beds below and above $A$, acting as confining strata; $F$, height of water level in porous beds $A$, or, in other words, height in reservoir or fountain head; $D, E$, flowing wells springing from the porous water-filled bed $A$.

\section{ARTESIAN SLOPE.}

Fig. 5 shows a section of an artesian slope such as may be found in the Atlantic Coastal Plain. The dike shown in the figure, however,

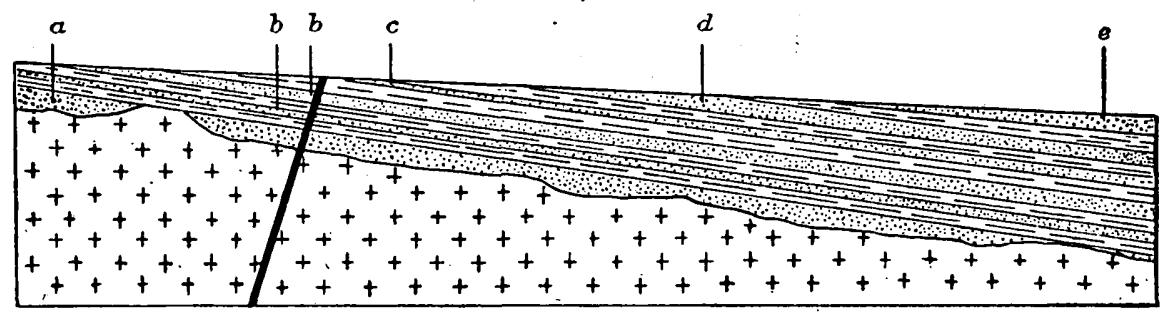

FIG. 5.-Section of an artesian slope. $a$, Water bed cut off by unconformity; $b$, beds cut off by dike; $c$, bed in which friction is the only obstruction to downward motion; $a$, porous bed changing to impervious; $e$, bed pinching out farther to the right.

does not usually occur in this area, although probable instances of such penetration occur in Georgia. 
UNCONFINED HORIZONTAL BEDS.

The deep valleys occupied by the harbors of northern Long Island . and some of the deep valleys in drift in northern Michigan present artesian conditions similar to those illustrated in fig. 6 .

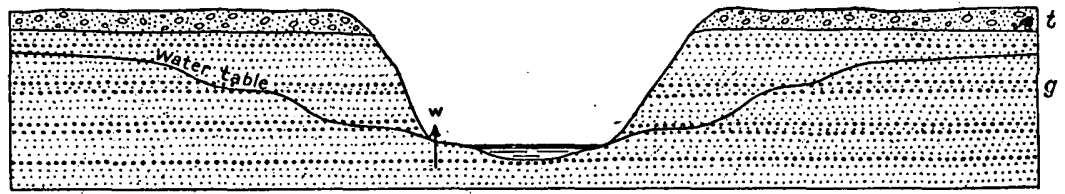

Fig. 6.-Section illustrating conditions governing flows from unconfined horizontal sands. $t$, Till; $g$, coarse sand and gravel; $w$, well.

\section{BEDDING PLANES.}

Conditions of artesian flow from horizontal bedding planes, fed by joints, are illustrated in fig. 7. A possible example of such conditions is afforded by the waters of the Trenton limestone in southwestern Ohio.

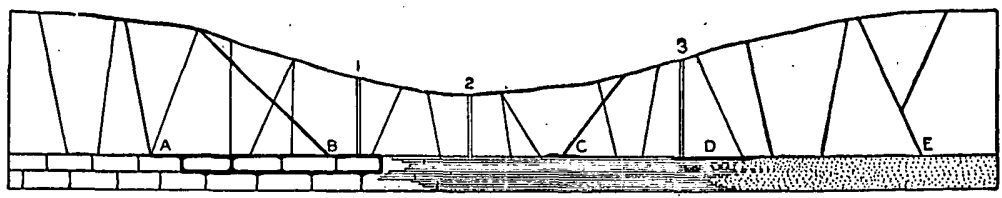

Fia. 7.--Section illustrating conditions of flow from horizontal bedding planes, etc., fed by joints. $A$, Water-bearing joints (indicated by the heavier lines); $B$, bedding planes between limestone and compact jointed rocks fed by joints at $A$ and $B$; $C$, bedding plane between shale and compact jointed rocks with local circulation only; $D$, bedding plane fed from sandstone bed; $E$, sandstone bed fed by joints. 1. Flowing well from bedding plane between limestone and compact jointed rocks; 2, dry hole (no circulation along bedding plane); 3 , flowing well from bedding plane fed from sandstone.

\section{SOLUTION PASSAGES.}

Some of the artesian flows of the Vicksbuirg limestone of the Atlantic Coastal Plain and of the Mississippian limestone of Kentucky may be cited as possible examples of flows from solution passages in limestone, illustrated in fig. 8.

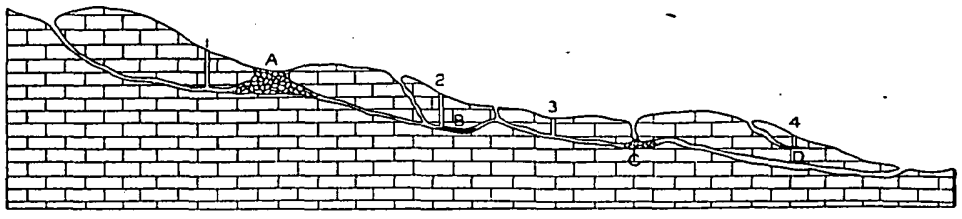

Fig. 8.-Section illustrating conditions of flow from solution passages in limestone. $A$, Brecciated zone (due to caving of roof), serving as confining agent to waters reached by well $1 ; B$, silt deposit filling passage and acting as confining agent to waters reached by well $2 ; C$, surface debris clogging channel and confining waters reached by well 3 ; $D$, pinching out of solution crevice resulting in confinement of waters reached by well 4 . 
FROST OR MINERAI CRUSTS.

The conditions of flow from beneath a frozen zone or mineral crust are represented in fig. 9. An example is seen in some of the open wells that overflow in spring.

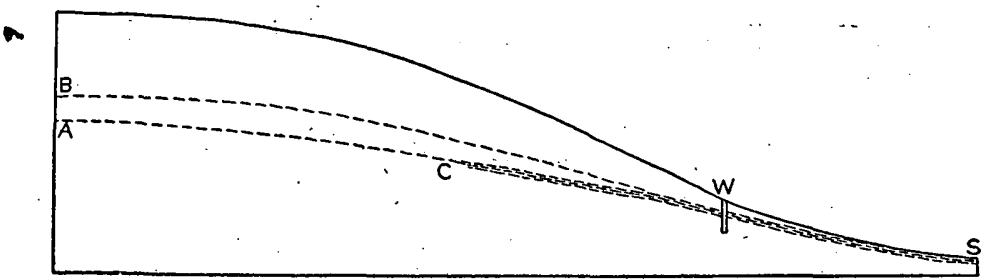

FrG. 9.- Section illustrating conditions of flow from beneath frozen zone or mineral crust. $C S$, Frost zone or mineral crust formed at surface of water table when at position $A C S ; B$, position of water table under increased rainfall; $W$, flowing well resulting from confinement of water due to rise of head from $A$ to $B$.

\section{VESICULAR TRAP,}

Fig. 10 illustrates conditions of flow from vesicular trap. Some of the wells penetrating the traps of the Newark group may be possible examples.

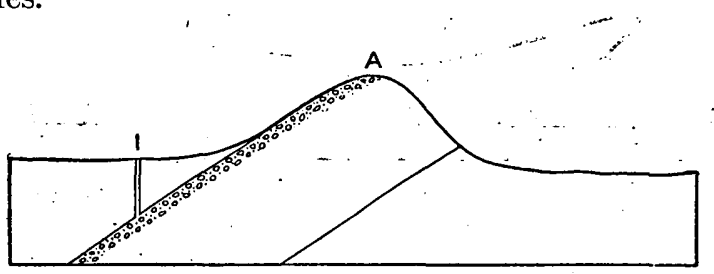

Fra. 10.-Section illustrating conditions of flow from vesicular trap. $A$, Vesicular zone feeding well 1 .

WEATHERED ROCKS BENEATH CLAYS.

The "lake bed" area of southeastern Michigan furnishes an instance of the conditions of flow shown in fig. 11.

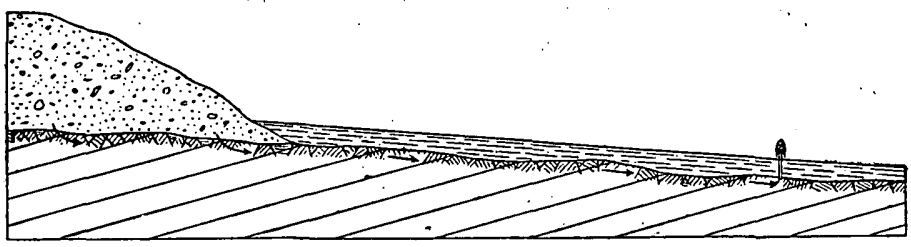

FrG. 11.-Section illustrating conditions of flow from joints, cracks, and solution passages in stratified rocks covered by impervious clays and fed from morainal drift. 
JOINTED CRYSTALLINE ROCKS.

Artesian conditions in jointed crystalline rocks without surface covering are represented by the flowing wells in the granites of Maine and New Hampshire and are illustrated in fig. 12.

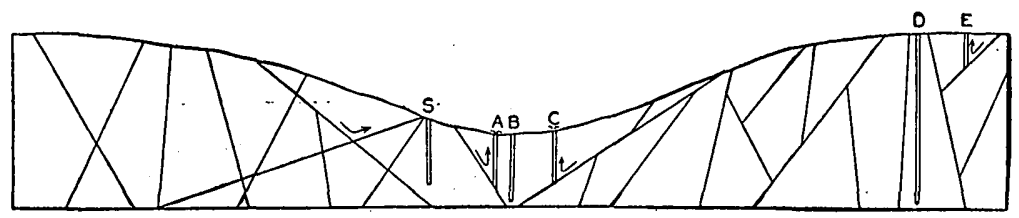

FIa. 12.-Section illustrating artesian conditions in jointed crystalline rocks without surface covering. $A, C$, Flowing wells fed by joints; $B$, intermediate well between $A$. and $C$ of greater depth, but with no water; $D$, deep well not encountering joints ; $E$, pump well adjacent to $D$, obtaining water at shallow depths; $S$, dry hole adjacent to a spring, showing why wells near springs may fail to obtain water.

BASINS FED BY JOINTS.

Many of the basins between mountain ranges throughout the arid West illustrate the conditions of flow shown by fig. 13.

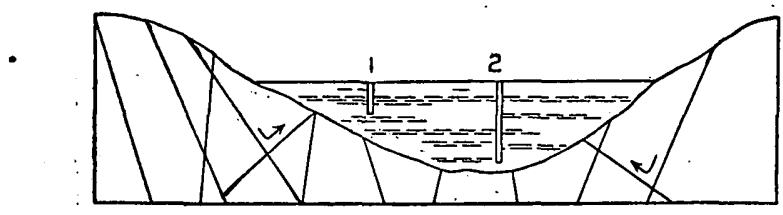

Fig. 13.- Section illustrating conditions of flow in alluvium-filled basins fed by joints. 1 and 2, Flowing wells from gravels beneath silts, fed from joints that carry water from surrounding mointains.

JOINT WATERS CONFINED BY ALLUVIUM.

The confinement of water in joints by valley silts, illustrated in fig. 14, occurs in many of the valleys of the Atlantic Piedmont Plateau.

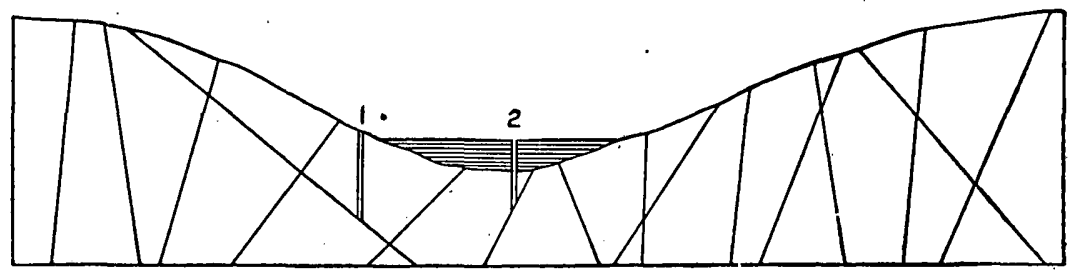

FIG. 14.-Section illustrating confinement of water in joints by valley silts. 1, Flowing hillside well resulting from obstruction of lower outlet by valley. silts; 2, valley well failing to secure supplies because of action of silts in preventing entrance of water into the joints. 


\section{JOINT WATERS CONFINED BY SEA WATER.}

Fig. 15 presents a section illustrating the action of salt water as a confining agent. Some of the low flowing wells near the coast of Maine and New Hampshire may be cited as possible examples.

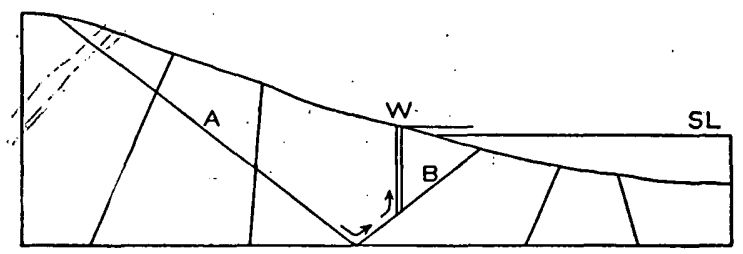

Frg. 15.-Section illustrating action of salt water as a confining agent, etc. $S L$, Sea level; $A$, open joint bringing down fresh water ; $B$, open joint communicating pressure from heavier salt water; $W$, well slightly above sea level, obtaining flow in consequence of slight rise in head resulting from slightly greater pressure of water in joint $B$ as compared to the water column in the well, due to the bigher specific gravity of the salt water.

\section{FOLIATION PLANES.}

The section shown in fig. 16 illustrates the conditions of flow from foliation and schistosity planes, examples being found in the flows from upturned schistose slates in Maine.

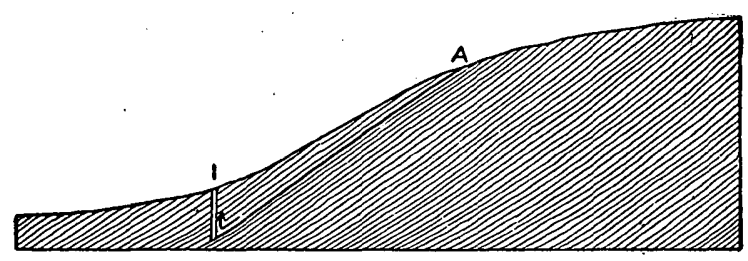

Fig. 16.-Section illustrating conditions of flow from foliation and schistosity planes. A, Foliation plane feeding flowing well 1.

FAUIT AND CONTACT PLAÑES.

Possible conditions of flows from fault and contact planes are shown in ideal section in fig. 17. Poland Springs, Maine, presents an example of such conditions.

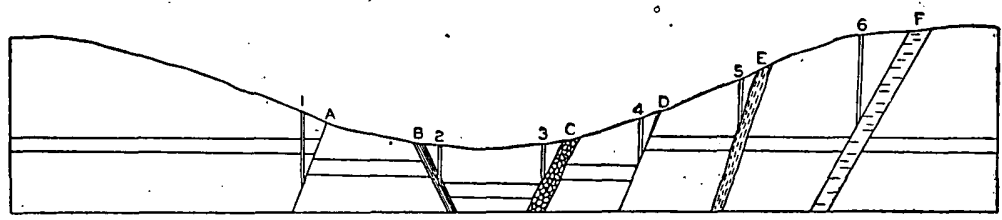

FIG. 17.-Ideal section illustrating possible conditions of flow from fault and contact planes. $A$, Reverse fault affording pump water to well 1 , but no flow; $B$, sheet zone due to normal faulting feeding flowing well $2 ; C$, crushed zone due to normal faulting yielding water to well $3 ; D$, simple normal fault feeding well $4 ; E$, vein affording water from contact to well $5 ; F$, dike affording water from contact to well 6 . $C, E$, or $F$, may also be conceived to represent sandstone dikes which may under certain conditions become important artesian reservoirs. 


\section{INDEX.}

A.

Air, confinement of water by.

Alluvium, flows due to, figure showing.... 42

Artesian, present significance of term ...... 7-8

Artesian basin, conditions in, figure showing..........................

Artesian circulation, factors in............ 27-33

Artesian flows, requisites of .............. 33-42

requisites of, modifying factors of ..... 37

supposed character of ............. 34-36

types of ............................. 37-42

Artesian slope, conditions in, figure showing ......................... 38

Atmosphere, water from

38

B.

Barometric pressure, effect of, on artesian circulation.

Basins, supply of, through joints, figure showing.......................

Bedded rocks; confining agents in....... 20,21-25

Bedding planes, flows from, conditions of figure showing.

flows from, conditions of, plate showing.

reservoir in .........................

spring from, plate showing

Beds; inclination of .

Blake, W. P., on caliche

Breccia, plate showing.

C.

Caliche, nature and effects of.............. 23

Cementation, confinement of water by...... 25

Centrosphere, water from ............... 19-20

Cephalonia, Sea Mills of, movement of water at.......................... 18, 30

Chamberlin, T. C., on impervious beds....

Chemical action, waters due to

Clays, confinement of water by ............

Clenvage planes, plate showing..............

reservoirs on....................... 15

Confining agents, necessity for . . . . . . . . 36-37

types of ......................... 20-27

Converging walls, water confined by ....... $\cdot 27$

Cracks, reservöirs in.................... 13

Crushed zone, plate showing............. 16

Crust, waters from ..................... 18-19

Crusts, mineral, confinement of water due

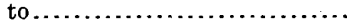

flows from beneath, conditions of, figure showing.
D.

Page.

Daniel, Alfred, on artesian circulation...... 28

E.

Earthquake, cracks from, plate showing.... 12 reservoirs due to $. . . \ldots \ldots \ldots \ldots \ldots \ldots, 13$

Ellis, E. E., on joints.................. 14

Erosion, underground, reservoirs due to ... 12

F.

Fault planes, flows from, figure showing... $\quad \cdot 42$ openings on, plate showing........... 16 reservoirs on ...................... 15

Flows, artesian, requisites of. See Artesian flows.

Folding, cracks due to, plate showing..... 12 flows from, figure showing......... 42

Foliation planes, reservoirs on ............ 15

Forbes, R. H., on caliche............... 23

Fracture openings, reservoir in ........... 13

Friction, confinement of water due to ...... 22

figure showing .................... 40 effect of, on artesian circulation. ...... 33

Frost fillings, water confined by .......... 26

Frost zones, confinement of water by ...... 23

G.

Gas, expulsion of, reservoirs due to........ Grain of rocks, effect of, on artesian circulation....................... 33

Gravity, artesian circulation due to....... 28

H.

Heat, confinement of water due to........ 25 water excluded by ................... 19

Hoskins, L. M., on rock flow........... 19

$$
\therefore \text {. } 1 \text {. }
$$

Igneous contacts, reservoirs on .......... 15

Impervious bed, deformation of........... 32 significance of term................ 21 transmission of pressure by .......... 32 unessentiality of ...................... $34-35$

Impervious wall, confinement of water by.. $\quad 26$

$$
\text { J. }
$$

Jointed rocks, confinement of water in . .... 26-27 plate showing ...................... 14

Joints, flow from, figure showing ......... . 41 interruption of, water confined by ..... 27 plates showing .................... 14 reservoirs on ..................... 13-14 
L.

Lakes, relations of, to underground water.. relations of, to underground water, figure showing.

Lamination planes, reservoir in ......... 17

Leakage, effect of, on artesian circulation .. $\quad 36$

Lee, W. T., on caliche................. 23

Lindgren, W., and Ransome, F. L., on joints. 14

Lithosphere, water from.

IV.

Magmatic waters, occlusion of . ............ Mechanically formed reservoirs, water in... Mineral crusts, confinement of water due to. flows from beneath, conditions of, figure showing

\section{o.}

Ocean, relations of, to underground water.. 17-18 relations.of, to underground water, figure showing ...............

Outcrop of porous stratum, unessentiality of.

\section{P.}

Pervious stratum, unessentiality of ........ Pores, original, reservoir in ............... Pores, secondary, reservoir in............. Porosity, effect of, on artesian circulation.. Precipitation, disposal of ............... 16-17 Pressure, confinement of water due to..... 25 effect of, on water circulation......... 33

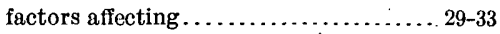
necessity for ..................... 36,37 water excluded by.

\section{$\mathrm{R}$.}

Rainfall. adequate, unessentiality of

Ransome, F. L., and Lindgren, W., on joints.

\begin{tabular}{|l|l} 
& Sch \\
& \\
& Sea \\
She & Sol \\
Solut & Strat \\
Str &
\end{tabular}

Schistosity planes, flows from, figure show-
ing $\ldots \ldots \ldots \ldots \ldots \ldots \ldots \ldots \ldots \ldots$

reservoirs on........................ 15

Sea water, inclusion of, in uplifted beds..... 18

Shearing planes, reservoirs on............ 15

Sheeting joints, plate showing........... 14

Solids, suspended, effect of, on artesian circulation.................... 30

Solution openings, reservoir in ........... 11-12

view of. $\ldots \ldots \ldots \ldots \ldots \ldots \ldots \ldots \ldots \ldots, 12,16$

Solution planes, flows from, conditions of, figure showing............... 39

Stratification planes, confinement of water by $\ldots \ldots \ldots \ldots \ldots \ldots \ldots \ldots \ldots .21$

Streams, relation of, to underground water. $\quad 17$ relation of, to underground water, figure showing .

Surface covering, impervious, water confined by ........................

water confined by, figure showing......

$\mathrm{T}$.

Temperature, effect of, on artesian circulation ..................... 29-30,33

Tides, effect of, on artesian circulation ..... 32

$$
\text { U. }
$$

Underground conditions, description of .... 8-27 See also Reservoirs, underground; Waters, underground.

\section{v.}

Vein contacts, reservoirs at............... 14

Vein fillings, water confined by $. \ldots \ldots \ldots \ldots . .26$

Vesicles, reservoir in................... 10

flow from, figure showing............. 40

W.

Water, fresh, confinement of other water by. $\quad 24$

Water, sea, confinement of other water by . 24,27

figure showing.................... 43

Water, underground, circulation of, factors

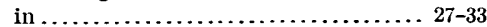

confining agents of...................... 20-27

necessity for .................... 36-37

density of, effect of, on artesian circulation ........................ 30

sources of ....................... 15-20

Water supply, adequate, necessity for...... 36-37

Water table, local, height of, effect of, on pressure ................... 31-32

Weathering products, waterconfined by.... 26

39 Wilmington, N. C., salt wells at........... 18

Sands, unconfined horizontal, flows from conditions of, figure showịng... 